\title{
Paracrine Regulation of Thyroid-Hormone Synthesis by C Cells
}

\author{
José María Fernández-Santos, Jesús Morillo-Bernal, \\ Rocío García-Marín, José Carmelo Utrilla and Inés Martín-Lacave
}

Additional information is available at the end of the chapter

http://dx.doi.org/10.5772/46178

\section{Introduction}

Thyroid hormone secretion by follicular cells is mainly regulated by thyroid-stimulating hormone (TSH) from the pituitary gland, which in turn is controlled by thyrotropin releasing hormone (TRH) of hypothalamic origin. However, there are a number of additional endocrine mediators, such as estrogens and corticosteroids, which are also involved in the regulation of the biosynthesis of $\mathrm{T}_{3}$ and $\mathrm{T}_{4}$. Besides this extrathyroidal main regulation, thyroid function and growth are under the influence of intrathyroidal peptides. Thus, there is evidence of the role played by some local factors released by nerve endings, such as vasointestinal peptide (VIP) or neuropeptide Y [1], by follicular cells themselves, such as insulin-like growth factors (IGFs) [2], and, specifically, by C cells through a paracrine mechanism, acting locally upon neighboring follicular cells [1]. This last intrathyroidal mechanism of regulation of follicular-cell activity by $\mathrm{C}$ cells is the main subject of the present review.

\section{Histological organization of the thyroid gland}

The thyroid gland consists of two lobes connected by a narrow band of thyroid tissue called the isthmus, located in the midportion of the neck, immediately in front of the larynx and trachea. Each lobe of the thyroid gland consists of numerous follicles, the thyroid follicles, which constitute the structural and functional unit of the gland. Each follicle consists of a simple layer of cuboidal epithelial cells, the follicular epithelium, enclosing a central lumen containing a colloid substance rich in thyroglobulin, an iodinated glycoprotein, yielding a periodic-Schiff (PAS)-positive reaction. The shape of the normal follicles varies from round to oval and they show a considerable size variation depending on the degree of gland activity (Figure 1). 
The thyroid follicles are composed of two different endocrine cell populations: (1) the follicular cells, the most abundant endocrine cells in the gland and responsible for secreting $\mathrm{T}_{3}$ and $\mathrm{T}_{4}$, hormones that control the basal metabolism; (2) C cells or parafollicular cells, which are very scarce and mainly known for producing calcitonin (CT), a hypocalcemic and hypophosphatemic hormone (Figure 1).

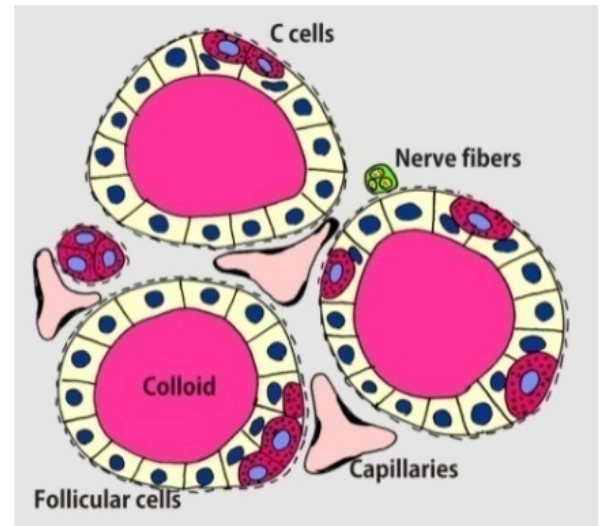

Figure 1. Schematic diagram of the histological components of the normal thyroid gland.

\subsection{Embryological development of the thyroid gland and origin of $\mathrm{C}$ cells}

The thyroid gland has a dual embryonic origin. Most of the thyroid gland derives from the medial anlage, a ventral outpocketing of the foregut endoderm at the level of the first pair of pharyngeal pouches. The medial anlage appears as a bilobulate vesicular structure at the foramen caecum of the tongue. It then descends as a component of the thyroglosal duct to reach its definitive position in the neck. After involution of the thyroglosal duct, the thyroid anlage begins to expand laterally to form two lateral lobes and a medial isthmus between them. Consequently, the medial anlage gives rise to most, if not all, of the follicular epithelium [3].

On the other hand, $\mathrm{C}$ cells derive from the ultimobranchial bodies (UBB), two outpocketings of the forth-fifth pharyngeal pouch complexes that lose their connection and migrate centrally to fuse with the medial thyroid anlage. Fusion typically occurs slightly above to the middle of the lateral lobes. After incorporation into the larger medial anlage, cells of the UBB disperse into the surrounding thyroid tissue and give rise to $C$ cells. UBB may also contribute to the formation of a minimal part of thyroid follicular cells [4]. Finally, portions of the UBB persist in the postnatal thyroid glands as small cystic structures -the "ultimobranchial follicles"- in rodents [5], or as "solid cell nests" in humans [6]. Estimates of the relative contributions to thyroid weight from the lateral anlage range from less than 1 to $30 \%$ in humans [7]. In non-mammal vertebrates, the embryonic thyroid and UBB develop as separate structures, thus, $C$ cells are confined to the ultimobranchial glands derived from the UBB, where they secrete calcitonin [8]. 
Since Le Douarin and Le Lievre study [9] confirmed, using chick-quail chimeras, that avian ultimobranchial $\mathrm{C}$ cells originate from the neural crests, it was assumed, without much supporting evidence, that mammalian thyroid $\mathrm{C}$ cells also originate from the neural crest via the UBB. Nevertheless, the neuroectodermical origin of $C$ cells in mammals is currently a controversial subject. In fact, Kameda et al. [10] have recently presented evidence that murine $C$ cells are derived from the endodermal epithelial cells of the last pharyngeal pouch -UBB- and do not originate from neural crest cells.

\section{2. $C$ cells as a member of the Diffuse Neuroendocrine System}

Classically, C cells formed part of the APUD system (term created by Pearse in 1966 [11] from the initial letters of Amine Precursor Uptake and Decarboxylation), a collection of cells of neuroectodermal origin, characterized by having as their primary function the production of endocrine peptides which are stored in secretory granules, and the common possession of a number of cytochemical and ultrastructural properties, in whatever situation they occur. Subsequently, further evidence indicated that only very few of the original series of APUD cells were definitively derived from the neural crests.

Nevertheless, according to Pearse [12], whenever APUD cells occur they could properly be regarded as "neuroendocrine cells" for synthesizing peptides (neuropeptides) common to both the nervous and endocrine systems. Additionally, as not all of these cells accumulate amine precursors, the designation APUD was finally replaced by Pearse in 1977 [12] with a new concept, the Diffuse Neuroendocrine System (DNES). The DNES includes, besides C cells, gastroenteroendocrine cells, pancreatic islet cells, bronchopulmonary and urogenital endocrine cells, adenohypophyseal cells, parathyroid cells and chromaffin cells of the adrenal medulla, carotid body, and sympathetic ganglia [13].

\subsection{Normal morphology and distribution of $\mathrm{C}$ cells}

$\mathrm{C}$ cells represent the neuroendocrine cells that produce calcitonin in the thyroid gland. Since their discovering by Baber in 1876, these cells have been given many different terms. However, the two most common denominations employed are $C$ cells and parafollicular cells. The name "C cell" was coined by Pearse in 1966 and it is reflective of calcitonin production; this term is preferred to that of "parafollicular cell" as these cells are not always related to follicles in parafollicular position and may, furthermore, be found outside the thyroid gland, unrelated to follicles, as occurs in the ultimobranchial glands in non-mammal vertebrates [11].

$C$ cells are difficult to identify in formalin-fixed, paraffin-embedded sections stained with H\&E. Generally, their nuclei are somewhat larger and paler than those of follicular cells. Therefore, the most reliable procedure for the identification of $\mathrm{C}$ cells involves the use of immunohistochemical procedures with antibodies for calcitonin (Figure 2).

$\mathrm{C}$ cells have variable shapes ranging from polygonal to spindled. The location of $\mathrm{C}$ cells relative to follicular cells also varies. They may be found between follicular cells or completely peripheral to the follicular epithelium. C cells are typically separated from the 
colloid by the cytoplasm of follicular cells and the basal aspects of $\mathrm{C}$ cells are usually in contact with follicular basal lamina. Occasionally, C cells emit cytoplasmic processes that surround adjacent follicular cells (see Figure 3). At ultrastructural level, many dense secretory granules are observed in the cytoplasm of $C$ cells $[13,14]$.

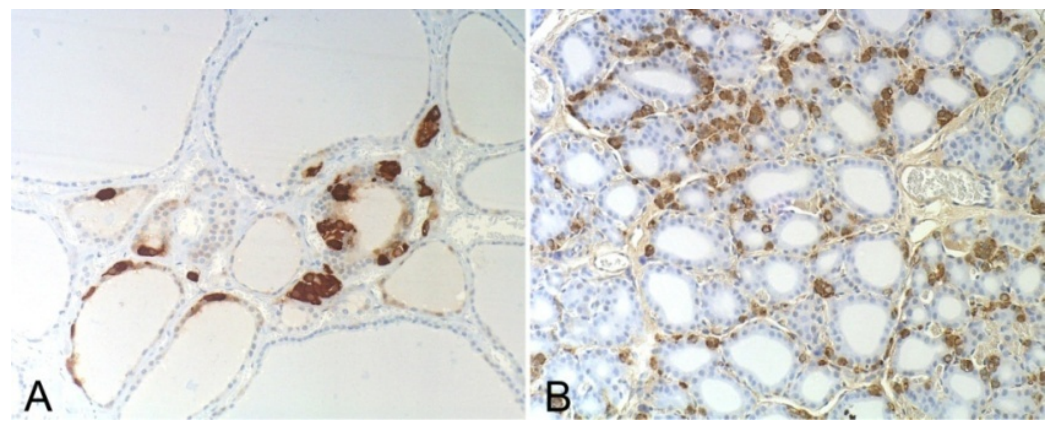

Figure 2. Visualization of $C$ cells using an immunohistochemical method for calcitonin. (A) Human thyroid gland; (B) Rat thyroid gland. C cells are more abundant in rat in comparison with the human thyroid gland. 200x.

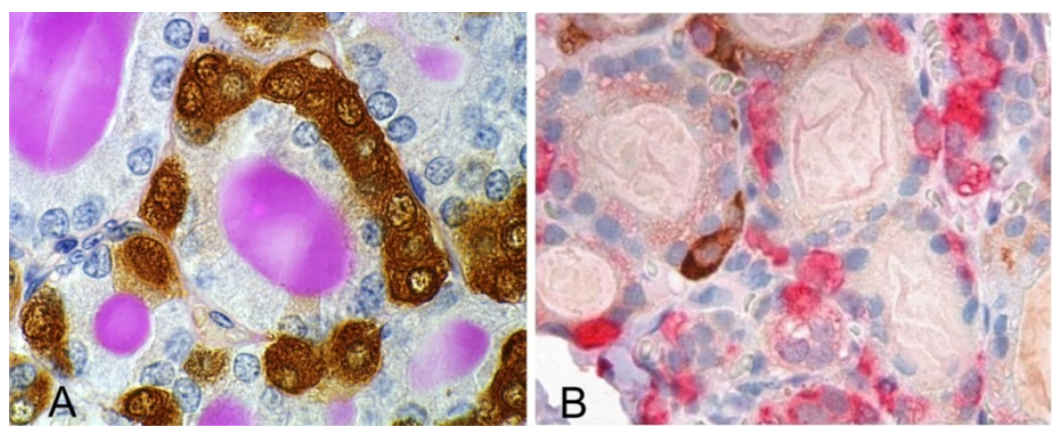

Figure 3. Immunohistochemical demonstration of $C$ cells in the normal rat thyroid gland. (A) Immunostaining for calcitonin followed by the PAS method for carbohydrates. (B) Double immunostaining for calcitonin (red) and somatostatin (brown). In Fig.A, the "parafollicular" ubication of $C$ cells can be observed. In Fig. B, all C cells are immunostained for calcitonin but only very few of them are also immunopositive for somatostatin. This somatostatin-positive $\mathrm{C}$ cell exhibits a cytoplasmatic process surrounding neighbouring follicular cells. (x500).

The distribution of $C$ cells within the thyroid lobes has also been reported to vary among species. In most species, C cells are located primarily in the centre of thyroid lobes, including humans [15, 16], mice [17], rats [18] and rabbits [17]. The area where $C$ cells predominate has been termed as 'C-cell region' [19], which is also the place where the mostactive follicles of the gland predominate [20]. In general, portions of the thyroid containing the highest concentration of $\mathrm{C}$ cells correspond to the typical fusion sites of between the UBB and the medial thyroid anlage. As another reminder of their embryonic origin, $\mathrm{C}$ cells could also be located within the parathyroid gland and thymus in some species, such as rabbits and cats [17]. 
The ratio of $\mathrm{C}$ cells to follicular cells in the thyroid gland differs markedly among species. In humans, $\mathrm{C}$ cells comprise less than $1 \%$ of the total endocrine-cell population [21], while the proportion of $C$ cells to follicular cells is at least $5 \%$ in rats [18]. Furthermore, $C$ cell concentration may vary according to age. In humans, however, data are very contradictory: Wolfe et al. in 1974 found that the number of $\mathrm{C}$ cells per unit area appeared to decrease with age [15], while Gibson et al. in 1982 found an age-dependant increase in C cells [16]. In contrast, thyroid glands of adult rodents have clearly more numerous $\mathrm{C}$ cells than those of neonates [14, 18].

\subsection{Substances synthesized by $\mathrm{C}$ cells}

The C cells share with other neuroendocrine cells the expression of different characteristic neuroendocrine markers, such as chromogranin, synaptophysin and NSE, with chromogranin A as the most reliable marker generally used to characterize cells of DNES (see Figure 4). Most of those neuroendocrine markers are shared with different populations of nervous cells (Table 1).

\begin{tabular}{lll}
\hline Neuroendocrine markers & Species & Authors \\
\hline NSE (Neuron-Specific Enolase) & Human & Lloyd et al. 1983 [22] \\
PGP 9.5 (Protein Gene Product 9.5) & Human & Thompson et al., 1983 [23] \\
Chromogranins (A, B) & Human & O'Connor et al., 1983 [24, 25]); \\
7B2 protein & Wuman, rat, pig & Marcinkiewicz et al., 1988 [26] \\
Synaptophysin & Human & Weiler at al., 1989 [25] \\
Secretogranin-II/chromogranin C & Human & Weiler at al., 1989 [25] \\
Secretoneurin & Human & Schmid et al., 1995 [27] \\
MMP-2 and MMP-9 & Human & Tomita, 1997 [28] \\
SV2 (Synaptic Vesicle Protein 2) & Human & Weiler at al., 1989 [25] \\
PC1 and PC2 (Prohormone Convertases) & Mouse & Kurabuchi et al., 2002 [29] \\
\hline
\end{tabular}

Table 1. Characteristic substances identified in different neuroendocrine cells, including $\mathrm{C}$ cells, according to a chronological order.

In addition to calcitonin, C cells may also contain many other regulatory peptides (Table 2), such as calcitonin gene-related peptide (CGRP) [30], katacalcin [31] or GRP [32]. Somatostatin has also been identified within $C$ cells of most species. In the adult rabbits, bats and guinea pigs, most calcitonin-positive cells also contain somatostatin; however, in adult human and rat thyroid glands, only a small proportion of the calcitonin-positive cells are also somatostatin positive [33]. Similarly, peptides including neuromedin U [34] and helodermin-like peptide [35], have been demonstrated to colocalize with CT in normal C cells. Lately, a new generation of regulatory peptides, similar to those characteristically found in some hypothalamic nuclei, such as TRH [36], CART [37] or ghrelin [38], has increased the long list of substances synthesized by $\mathrm{C}$ cells. 


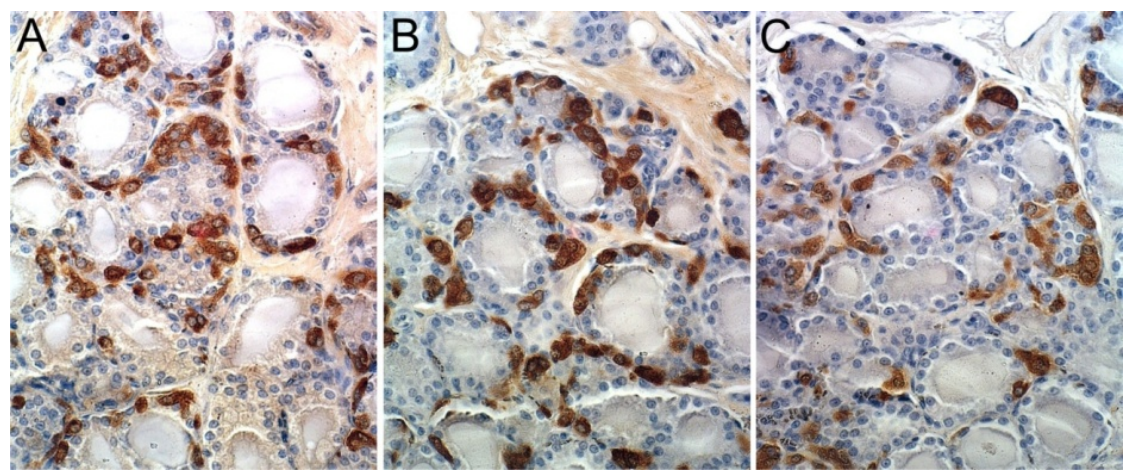

Figure 4. Immunohistochemical demonstration of chromogranin A (A), calcitonin (B) and CGRP (C) in consecutive sections of the rat thyroid gland. All $\mathrm{C}$ cells express the different markers, being slightly less intense CGRP-positive C cells. (x400).

\begin{tabular}{|c|c|c|}
\hline Regulatory factors & Species & Authors \\
\hline Calcitonin (CT) & Pig, dog & $\begin{array}{l}\text { Bussolati and Pearse, } 1967 \\
\text { [39] }\end{array}$ \\
\hline Somatostatin & Mammals & Kameda et al., 1982 ([33] \\
\hline Katacalcin-I/CCP-I/PDN-21 & Human & Ali-Rachedi et al., 1983 [31] \\
\hline $\begin{array}{l}\text { CGRP (Calcitonin Gene-Related } \\
\text { Peptide) }\end{array}$ & Mammals & $\begin{array}{l}\text { Sabate et al., } 1985[30,40] ; \\
\text { Kameda, } 1987[30,40]\end{array}$ \\
\hline Serotonin & Sheep & Barasch et al., 1987 [41] \\
\hline GRP (Gastrin-Releasing Peptide) & Human & Sunday et al., 1988 [32] \\
\hline Helodermin-like peptide & Human, rat, pig, dog, etc. & Grunditz et al., 1989 [35] \\
\hline CCK/ C-terminal gastrin & Rat & Arias et al., 1989 [42] \\
\hline TRH (Thyroid Releasing Hormone) & Rat & Gkonos et al., 1989 [36] \\
\hline Neuromedin U & Rat & Domin et al., 1990 [34] \\
\hline $\begin{array}{l}\text { CCP-II (CT Carboxyl terminal } \\
\text { Peptide) }\end{array}$ & Human & Cohen et al., 1992 [43] \\
\hline $\begin{array}{l}\text { PTHrP (Parathyroid Hormone- } \\
\text { related Protein) }\end{array}$ & Sheep & Okada et al., 1995 [44] \\
\hline Melatonin & Rat & Kvetnoy, 1999 [45] \\
\hline Neuropéptide Y & Human & Scopsi et al., 1990 [46] \\
\hline Ghrelin & Rat, human & Raghay et al., 2006 [38] \\
\hline Pneumadin & Rat & Kosowicz et al., 2003 [47] \\
\hline $\begin{array}{l}\text { CART (Cocaine- and Amphetamine- } \\
\text { Regulated Transcript) }\end{array}$ & Pig & Wierup et al., 2004 [37] \\
\hline Motilin & Human & Xu et al., 2008 [48] \\
\hline $\begin{array}{l}\text { NERP (NeuroEndocrine Regulatory } \\
\text { Peptide) }\end{array}$ & Human & Matsuo et al., 2010 [49] \\
\hline
\end{tabular}

Table 2. Regulatory factors identified in the cytoplasm of C cells, according to a chronological order. 
In addition to the regulatory peptide products, $\mathrm{C}$ cells also contain a variety of biologically active amines including serotonin [41] and melatonin [45] (see Table 2). Additionally, C cells are also implicated in the synthesis of many other different substances, such as tetranectin [50] or CEA [51] (see Table 3).

\begin{tabular}{|c|c|c|}
\hline Other substances & Species & Authors \\
\hline CEA (Carcinoembryonic Antigen) & Human & Kodama et al., 1980 [51] \\
\hline Tetranectin & Human & Christensen et al., 1987 [50] \\
\hline $\begin{array}{l}\text { PAM (Peptidylglycine Alpha-amidating } \\
\text { Monooxygenase) }\end{array}$ & Rat & Braas et al., 1992 [52] \\
\hline E-cadherin & Rat & $\begin{array}{l}\text { Nishiyama et al., } 1996[10,53] \text {; } \\
\text { Kameda et al., } 2007[10,53]\end{array}$ \\
\hline NCAM (Neural Cell Adhesion Molecule) & Rat & Nishiyama et al., 1996 [53] \\
\hline $\begin{array}{l}\text { RESP18 (Regulated Endocrine-Specific } \\
\text { Protein 18) }\end{array}$ & Rat & Darlington et al., 1997 [54] \\
\hline c-erbB-2-like product & $\begin{array}{l}\text { Human, } \\
\text { guinea pig }\end{array}$ & $\begin{array}{l}\text { Martín-Lacave and Utrilla, } \\
2000 \text { [55] }\end{array}$ \\
\hline
\end{tabular}

Table 3. Other substances synthesized by C cells, according to a chronological order.

\subsection{Paracrine role played by $\mathrm{C}$ cells}

Apart from their role in calcium homeostasis, C cells are also probably involved in the intrathyroidal regulation of follicular cells. This hypothesis is supported by different features, such as their characteristic 'parafollicular' position, their predominance in the central region of the thyroid lobe - the so-called "C-cell region" [19]- where the most-active follicles of the gland predominate [20], and their implication in the secretion of many different regulatory factors $[1,46,56]$. Some of these regulatory peptides display an inhibiting action on thyroid hormone secretion, such as calcitonin, calcitonin gene-related peptide (CGRP) and somatostatin [1], whereas others act as local stimulators of thyroid hormone synthesis, such as gastrin-releasing peptide (GRP), helodermin, and serotonin [35, $57,58]$. For any of those peptides, a requirement to exert an effective paracrine regulation of follicular cells is the presence of their specific receptors in this endocrine cell population. At this point, the existence of some of those receptors on follicular cells, such as somatostatin or serotonin receptors, has already been described [58,59]. Furthermore, we have recently demonstrated the expression of TRH-receptor on follicular cells [60].

There is additional evidence that $C$ cells and follicular cells somehow interact functionally. Thus, $\mathrm{C}$ cells, in the normal-appearing thyroid tissue adjacent to follicular tumours, have been reported to display reactive changes. These changes may include the development of a $C$ cell hyperplasia [61] or the presence of an increased percentage of immunopositive $C$ cells for GRP [32] or somatostatin [62], being the latter a potent inhibitor of TSH-enhanced mitotic activity and $\mathrm{T}_{3}$ and $\mathrm{T}_{4}$ synthesis by follicular cells. Moreover, we have found hyperplastic changes in the C-cell population of rat thyroid glands in a model of non-hypercalcemic hypothyroidism induced by propylthiouracil administration [63]. As we have recently 
demonstrated the presence of TSH receptors on C cells [64], we can infer that those hyperplastic changes may be due to the corresponding increased TSH-serum levels. Nevertheless, the influence of local secretion of growth factors by follicular cells themselves, or by the surrounding tissue could not be discarded.

The main secretagogue of $C$ cells is calcium, which is concordant with the classical role of calcitonin as a plasma calcium- and bone metabolism-related hormone. Nevertheless, C-cell activity appears to be subjected to a more complex regulation, for which different regulatory peptides, either with inhibitory (somatostatin) or stimulatory effect (glucagon, pentagastrin), have being reported [65]. Furthermore, Suzuki et al. in 1998 [66] reported that C cells expressed the thyroid transcription factor 1 (TTF-1), which is typically expressed by follicular cells and known for its critical role in thyroid-specific gene expression. According to these authors, TTF-1 is calcium-modulated and coordinately regulates genes involved in calcium homeostasis in C cells. All these data constitute new evidence of interdependence between the two endocrine cell populations of the thyroid gland.

\section{Description of the different regulatory factors synthesized by $\mathrm{C}$ cells and their potential effects on thyroid hormone synthesis}

The most important objective of the current review is to present new evidence of the paracrine regulation exerted by $\mathrm{C}$ cells upon follicular cells, through the secretion of numerous factors synthesized by $\mathrm{C}$ cells in the immediate vecinity of the follicular epithelium, which could act in a synergistic or antagonist manner. To accomplish that objective, we will expose the functional role played by the most studied C-cell secreted factors on the activity of follicular cells mediated through their specific receptors.

\subsection{Calcitonin and calcitonin family of peptides}

In 1961, Copp et al. were the first in postulating the existence of a hypocalcemic hormone secreted by the thyro-parathyroid complex which was named calcitonin (CT) [67]. Subsequently, in 1963, Kumar et al. [68] confirmed the secretion of this hypocalcemic hormone by the thyroid gland. The evidence that parafollicular cells contained calcitonin was provided by immunofluorescent techniques in dog and pig thyroids [39], and these findings led to the name of ' $\mathrm{C}$ ' cells for parafollicular cells. In more recent years, however, accumulating evidence supports the existence of nonthyroidal calcitonin or CT-like peptides in brain, prostate and uterus, although their biological role is unknown [69].

Calcitonin is expressed in many species including fish, amphibians, reptiles, birds and mammals, and it is normally a 32 amino acid peptide with a carboxy terminal proline amide and a disulfide bridge between cysteine residues at positions 1 and 7 [70, 71]. The CT amino acid sequence in the amino terminal loop region is highly conserved within species, but displays less homologies in the rest of the sequence [69].

The hypocalcemic action of calcitonin is due to inhibition of bone resorption and to effects on other tissues indirectly related to bone remodeling such as kidneys. Additional cellular actions of calcitonin include its effect on the growth of breast cancer cells [72]. 
Calcitonin is synthesized as a 136 amino acid precursor which is processed by proteolytic cleavage and by amidation of the carboxy terminal proline residue before being secreted. The gene transcript encoding CT also encodes calcitonin gene related peptide (CGRP), another peptide in the CT family of peptides. The CT/CGRP gene was one of the first described examples of tissue-specific alternative RNA processing, it has six exons, of which the first four are spliced together to generate calcitonin mRNA in C cells, which encodes calcitonin and katacalcin (CCP), while the transcripts from CT/CGRP gene in neurons are processed into CGRP mRNA containing exons 1-3, 5 and 6 [30, 73] (see figure 5). In thyroid C cells $95 \%$ of the transcripts encode calcitonin, while more than $98 \%$ of the transcripts encode CGRP in the nervous system [69].

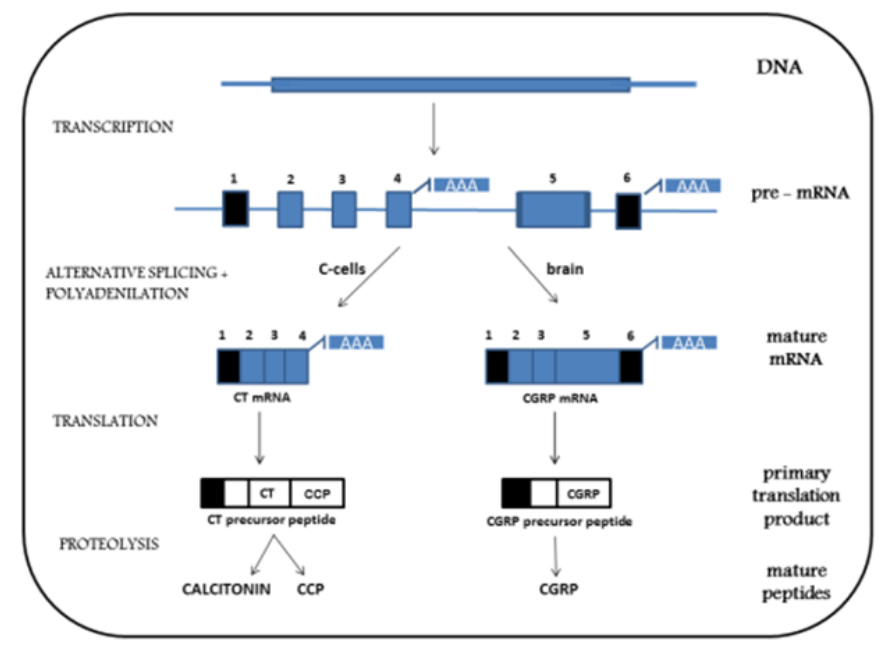

Figure 5. Schematic representation of alternative RNA processing of CT/CGRP gene. Transcription of the CT/CGRP gene produces a pre-mRNA, which has two polyadenylation sites. From the primary transcript two different mRNAs are produced, one coding for the calcitonin (CT)/katacalcin (CCP) precursor and the other coding for the CGRP precursor. The blue boxes indicate sequences complementary to exons, the lines between them are the sequences complementary to introns and the black boxes indicate the noncoding sequences of RNA.

The alternative product of the CT/CGRP gene, a neuropeptide referred to as CGRP, is a 37 amino acid peptide widely expressed in nerves in both the central and peripheral nervous systems and in several neuroendocrine tissues [74]. CT and CGRP have some homologies in the amino terminal region, but are almost entirely different in the rest of the molecule [74]. CGRP is a potent vasodilator, relaxant of mesangial cells and has functional roles in response to painful stimuli [75].

CT interacts with a member of seven-transmembrane-domain G-protein-coupled receptor superfamily cloned in 1991 [76]. High-affinity CT receptors (CTRs) were characterized on isolated osteoclasts, the physiological CT target cells. Moreover, calcitonin receptors have been identified in a variety of tissues, such as brain, testis, spermatozoa, kidney, skeletal 
muscle, breast cancer cell lines and human primary breast cancer cells [77]. Numerous studies have demonstrated that multiple CTR mRNA isoforms are present in a number of species. In humans, two isoforms (h-CTR1 and h-CTR2) differing by a 16 amino-acid insert in the first intracellular loop have been reported [78]. Finally, studies have revealed h-CTR2 expression in normal thyroid glands, in medullary thyroid carcinoma (MTC), and in a model of human MTC cell line (TT), suggesting an autocrine regulation of CTR in C cells [79]. Nevertheless, there is still no evidence of the CTR expression in follicular cells.

A family of receptors for CGRP and CT has been demonstrated throughout the nervous systems of both man and rat. CGRP-specific binding sites have been found in the cerebellum, spinal cord and other brain regions including vessels and pia mater. In contrast to calcitonin receptors found in bone, these receptors are not linked to adenylate cyclase, however, CGRP stimulates adenylate cyclase activity by acting at the calcitonin receptor in more than one tissue. Furthermore, specific cAMP linked CGRP receptors have been identified both in the intima and media of vessels as well as the atria and ventricles of the heart [80]. Seifert et al. [81] demonstrated the presence of a novel specific receptor for CGRP in the acinar cells of the pancreas. Finally, specific CGRP binding has also been demonstrated on cloned lung and bone cancer cells [82].

CGRP has a double location in the thyroid, one in nerve fibers around blood vessels and follicles and the other in $\mathrm{C}$ cells. This may suggest a functional role on the follicular cells; however, it seems not to affect basal or TSH-stimulated thyroid hormone secretion [83]. In contrast, CT, CGRP and katacalcin, which have been demonstrated to have no effect on basal and TSH-stimulated thyroid hormone secretion when separately administered alone, inhibited TSH-stimulated thyroid hormone secretion when the three peptides were applied together [83]. Despite this, further studies about the CTRs or calcitonin like receptors (CLRs) expression in follicular cells are necessary to dilucidate the role of CT/CGRP family peptides in the thyroid gland function.

\subsection{Somatostatin}

Somatostatin (SS) was first identified in 1973 in ovine hypothalamus as a tetradecapeptide (SS-14) with a disulfure bond between 3 and 14 cysteines. Its main function was to inhibit the release of growth hormone [84]. Subsequently, a big family of functional and structural peptides related to somatostatin was discovered. Over the years several forms of somatostatin depending on the tissue and species have been described.

SS-like immunoreactivity has been found in all vertebrates as well as in some invertebrate species and in the plant kingdom. SS-producing cells occur at high densities throughout the central and peripheral nervous systems, such as the hypothalamus, pituitary, cerebellum, limbic lobe, retina, sympathetic ganglia and the vagus and sciatic nerves. SS-producing cells have also been reported in the endocrine pancreas, the gut and in small numbers in the thyroid, adrenals, submandibular glands, kidneys, prostate, and placenta [85-87].

SS has many physiological actions, it functions as a neurotransmitter in the brain with effects on cognitive, locomotor, sensory, and autonomic functions [88]. Moreover, it has 
inhibitory effects on the endocrine system, gut exocrine secretion, adrenal glands, kidneys, and on proliferation of lymphocytes, cartilage and bone precursor cells $[86,87,89,90]$. Other effects consist on the inhibition of the release of growth factors (IGF1, EGF, PDGF) and cytokines (IL6, IFN-g) [91]. All of these diverse effects of SS can be explained by the inhibitory actions of the peptide on two key cellular processes: secretion and cell proliferation.

The above-listed functions of SS are mediated by a family of receptors that recognizes these ligands with different affinities [92]. Originally, five different somatostatin receptor types (SSR1-5) were identified, cloned and found able to bind not only native SS forms (SS-14 and SS-28), but also their synthetic analogues [93]. SS receptors belong to the family of G protein-coupled receptors, typically consisting of extracellular domains forming the ligand binding site, a single polypeptide chain with seven transmembrane domains and intracellular domains mediating signal transduction. Each SS receptor subtype mediates different biological actions of SS, via the activation of different intracellular systems such as inhibition of adenylate cyclase (with decrease of intracellular cyclic AMP levels), reduction of intracellular calcium levels, and stimulation of phosphotyrosine phosphatase or MAP kinase activity [94].

Within the thyroid, SS coexists with CT in a subpopulation of C cells, with a variable extension. Thus, while the frequency for somatostatin-immunoreactive (SS-IR) CC varies in rats throughout their lives, as they are scarce in the foetus, abundant at the time of birth and scarce again in adults (see Figure 6) [33, 95-97], the majority of calcitonin immunoreactive (CT-IR) CC in guinea pigs and rabbits are also SS-IR, besides positivity is seen in the parathyroid gland [33]. On the contrary, SS-IR CC are observed very occasionally in normal pig and human thyroid glands [98].

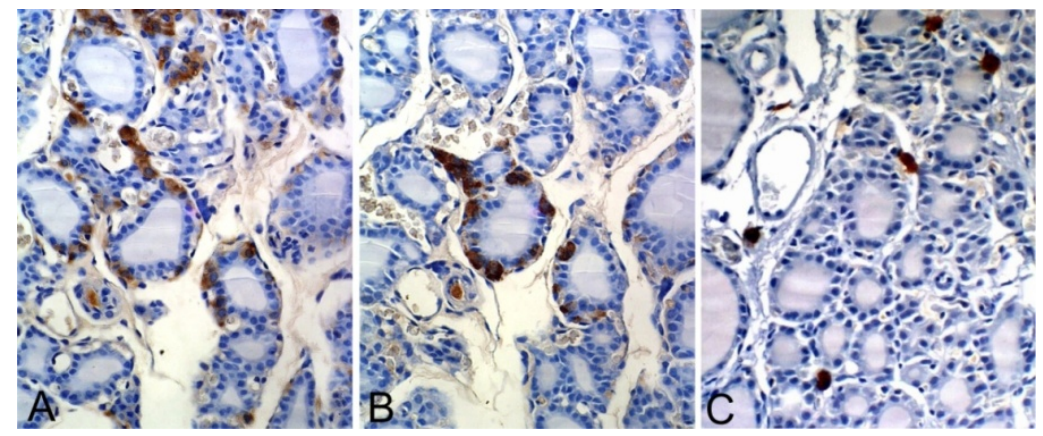

Figure 6. Immunohistochemical demonstration of calcitonin (A), somatostatin (B) and serotonin (C) in consecutive sections of the rat thyroid gland. Only a subpopulation of calcitonin-positive $C$ cells is also immunopositive for somatostatin. Serotonin is exclusively located in mast cells, being $\mathrm{C}$ cells negative in the rat. (x400).

The effects of SS on the thyroid include the inhibition of the TSH-stimulated release of $\mathrm{T}_{4}$ and $\mathrm{T}_{3}$ [99], as well as the inhibition of TSH-stimulated radioiodine turnover accumulation in thyroid glands of euthyroid volunteers [100]. SS inhibition of basal as well as TSHstimulated adenyl cyclase activity has been demonstrated in normal and neoplastic human 
thyroid tissues [101] as well as in cultures of human thyrocites [102]. Besides its effects on thyroid function, suppression of thyroid follicular cell growth has been demonstrated by the inhibition of both TSH and IGF-1 proliferative stimulation [103].

These evidences of the expression of SS in thyroid, more precisely limited to the C cells, and the actions in the follicular cells have led us to the speculation that this peptide could elicit local effects on thyroid hormone release acting locally in a paracrine fashion.

\subsection{TRH}

Thyrotropin-releasing hormone (TRH) is a tripeptide (pGlu-His-ProNH2) that was originally described to be synthesized in the mammalian hypothalamus, released into the hypothalamic-pituitary portal system and has the capability of inducing the release of thyroid-stimulating hormone (TSH) from the anterior pituitary [104, 105]. TRH binds to specific seven transmembrane domain, Gq/11-protein-coupled receptors of which, two subtypes have been cloned and characterized so far: TRHR1 and TRH-R2 [106, 107]. The two receptor subtypes exhibit similar affinities to TRH but different tissue distribution [108] and basal activities [109].

Besides stimulation of TSH secretion at the pituitary, main role of TRH as key factor in the hypothalamic-pituitary-thyroid axis, numerous morphological and pharmacological studies have described TRH as neurotransmitter or neuromodulator in the CNS affecting behaviour, temperature regulation, food intake, and nociception [110, 111]. Furthermore, as suggested by the wide tissue-distribution of TRH and TRH receptors, TRH is implicated in many physiological and pathological processes of prostate, pancreas, testis, adrenal gland, heart, skin and thyroid tissues [112-119].

In the case of thyroid, it has been well established that $C$ cells express TRH at both mRNA and protein levels (see Figure 7) [36]. Furthermore, our research group have described that C-cell cultures express TRH-R1 and TRH-R2, whereas only TRH-R2 subtype is expressed by PC-Cl3 rat thyrocytes [60]. It has also been reported that TRH inhibits the TSH-induced increase of cAMP and subsequent release of thyroid hormones by the dog thyroid gland [120, 121], suggesting that TRH could participate in the regulation of thyroid hormone secretion as an antagonist to TSH [122].

In accordance to this point, Rausell et al. in 1999 [122] found that the levels of TRH and TRH-like peptides in the thyroid were strongly influenced by thyroid status. Furthermore, Rausell et al. demonstrated that TRH exerted a direct effect on thyroid hormone release in vitro [123] and administration of TRH to hyperthyroid patients with very low levels of TSH resulted in decreased levels of circulating thyroid hormones [124].

Although the effects of TRH on thyroid hormone secretion could, at least in part, be due to hypothalamic TRH, the results so far published in the literature and reviewed above would open the possibility of a paracrine regulation of follicular cell activity through C-cell released TRH as a putative additional mechanism for thyroid function. 

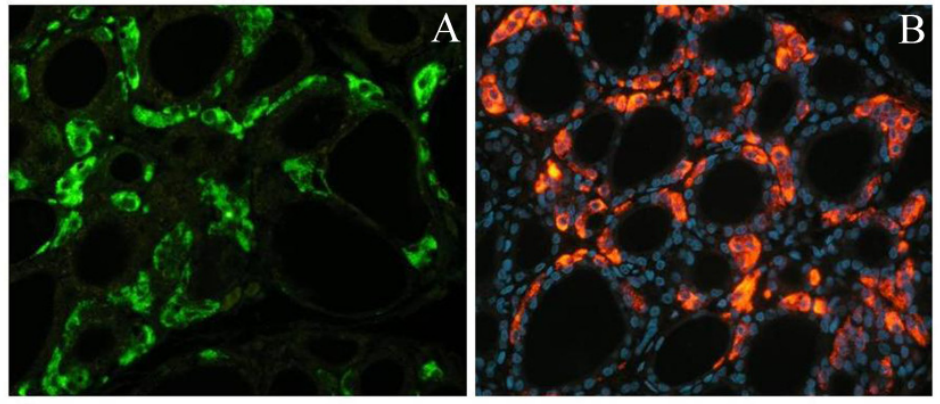

Figure 7. Immunofluorescent staining for calcitonin (A) and TRH (B) in rat thyroid tissue. All calcitonin-immunopositive $\mathrm{C}$ cells are also immunopositive for TRH. (x400).

\subsection{Ghrelin}

Ghrelin, is a 28 amino-acid acylated-peptide with powerful GH-releasing, orexigenic and adipogenic functions that, at hypothalamic level, regulates appetite, food-intake and energy metabolism in mammals [125, 126]. Since its initial description in 1999 [125], a variety of new functions for ghrelin have been characterized in the literature. Thus, apart from its GHreleasing and orexigenic effects, ghrelin has been reported to influence sleep and behaviour $[127,128]$, and the pituitary-gonadal axis at both peripheral [129] and central levels [130, 131].

The enteroendocrine cells of the stomach mucosa are the main source of circulating ghrelin [132]. Ghrelin synthesis and plasma levels rise and fall in relation to food intake, increasing with fasting and decreasing after eating [133, 134].Besides its gastric secretion, ghrelin is also expressed in many other tissues and organs $[38,135,136]$ and despite the fact that molecular mechanisms have not yet been characterized, recent investigations have implicated ghrelin in many pathological conditions of heart, bone, liver, kidney and, specifically thyroid tissues [137].

The first observation regarding the presence of ghrelin in thyroid tissue was that by Kanamoto et al. in 2001 [138], describing the production of ghrelin in human medullary thyroid carcinoma tissue. Also, Gnanapavan et al. in 2002 [139] showed a very low expression of ghrelin at mRNA level and suggested to be carried-out by a very minor thyroid cell-population in normal human thyroid tissue. Those findings were concordant to those from Volante et al. [140] who failed to detect ghrelin-immunopositive cells in normal human adult thyroid gland. This last fact, being probably due to the very scarce presence of $\mathrm{C}$ cells in the human adult thyroid gland as compared to rats, where their percentage, in relation to follicular cells, ranges from 4.5 to $10.4 \%$ [18]. These observations were supported by the study by Raghay et al. in 2006 [38] in which ghrelin was described in the thyroid gland to be synthesized only by $\mathrm{C}$ cells.

Moreover, the ghrelin functional receptor has been demonstrated to be expressed in the neighbouring follicular cells [141], supporting, one more time the idea, increasingly found in the literature, that $C$ cells would modulate thyroid function $[38,60,63,64]$, in this case, in a paracrine fashion, via ghrelin. Addressing this last point, up to date there are evidences 
that would help to elucidate some aspects of this putative new mechanism. Thus, Volante et al. showed differences in ghrelin content in foetal and pathologic thyroid as compared to normal adult glands, [140]. Moreover, Park et al. [141] demonstrated that ghrelin, via GHSreceptor and calcium signalling, enhanced the TSH-induced proliferation of FRLT5 rat follicular cells, suggesting the thyroid function as a target for ghrelin, via GHS-receptor and protein kinase $\mathrm{C}$, one of the key signal-pathways for thyroid follicular-cell function and thyroid hormone synthesis [142].

In regard to the implication of ghrelin in thyroid hormone synthesis, after the demonstration of the ghrelin receptor in human thyroid tissue [143], Kluge et al. [144] described a ghrelinmediated decrease in TSH levels and an increase of serum $\mathrm{T}_{4}$, probably due to a ghrelin direct stimulatory action on the thyroid gland. These results has been supported by a study from our research group which have demonstrated that, effectively, ghrelin has a direct effect on the three tissue-specific genes involved in thyroid hormone synthesis: thryroperoxidase (TPO), $\mathrm{Na}^{+} / \mathrm{I}^{-}$symporter (NIS) and thyroglobulin [144, 145]. This direct effect on follicular-cell activity could be responsible for the effects observed at the hypothalamus-pituitary-thyroid axis [144, 145].

\subsection{CART}

Cocaine and amphetamine related transcript (CART) is an abundantly expressed and widely distributed neuropeptide that has been implicated in a number of physiologic processes. The existence of a CART peptide fragment was first reported by Spiess et al. in 1981 in extracts of ovine hypothalamus as a somatostatine-like polypeptide [146], but its functional significance was not explored further. Almost fifteen years later, Douglass et al. found the first evidence of the existence of mRNA encoding neuropeptide CART in the rat brain after psychostimulant drugs were administered [147].

CART gene is composed of 3 exons and 2 introns, with rats and mice having alternatively spliced variants resulting in the production of two peptides, the longest of which has 129 amino acids (ICART) while the shortest is composed by 116 amino acids (sCART) [148]. The C-terminal end of CART, consisting of 48 amino acid residues and three disulfide bonds, it is thought to constitute the biologically active part of the molecule, and several fragments, notably, rlCART 55-102 and rlCART 62-102, have been shown to be active in vivo. In humans, only the short form is expressed (116 amino acids).

Distribution of CART mRNA and peptides has been demonstrated by several techniques showing a wide distribution throughout the nervous system, including sensory processing areas, central autonomic control areas, pathways involved in drug reward and reinforcement (nucleus accumbeus, lateral hypothalamus and projections to dopaminergic ventral tegmental area neurons), areas controlling feeding and body weight (hypothalamic nuclei), and stress related brain regions [149-152]. Furthermore, CART expressing cells have been found in the anterior pituitary, adrenal gland, islets of Langerhans, myenteric plexus of small intestine and in the ovary [153, 154]. Wierup et al. [155] reported for the first time the existence of CART IR in C cells in the porcine thyroid, in addition to porcine pancreas, 
gastrointestinal tract and adrenal gland, thus suggesting that the widespread expression of CART reveals a role for CART as modulator of neurohormonal functions.

Besides as nervous system neurotransmitters, CART peptides have been implicated in the regulation of feeding and body weight, drug reward and reinforcement and other processes [156]. They also have neuroprotective properties and promote the survival and differentiation of neurons in vitro [157]. Moreover, there is some evidence of its role as a modulator of anxiety and stress response [158].

While the importance of CART peptides is clear, little is known about the cellular mechanisms by which CART exert their effects. No receptor for CART peptides has yet been identified, but some cellular effects have been observed, such as the induction of c-Fos activity in brain areas that are related to feeding and energy expenditure [159] or the induction of phosphorylation of ERK in AtT20 cells [160] which activates the MAP kinase pathways.

Due to important CART roles in the regulation of food intake and energy balance, where the thyroid plays a relevant function, several studies have been focused in the effects of CART in the regulation of Hypothalamus-Pituitary-Thyroid axis (HPT) and whether the thyroid status could regulate the expression of CART in the hypothalamus. CART-IR neurons in the paraventricular hypothalamic nucleus are reported to co-express thyrotropin releasing hormone (TRH) in rats, this neuronal populations co-containing TRH and CART project their axons to the median eminence, suggesting that CART peptides may have an important role in the regulation of thyroid-stimulating hormone (TSH) in the anterior pituitary [161]. In 2002, López et al. [162] demonstrated the existence of functional interrelations of the HPT axis with CART peptides. In other studies, the importance of the CART signaling system in the regulation of the HPT axis is suggested by the potent stimulatory effect of CART on the TRH gene expression of hypophysiotropic neurons [163]. Intracerebroventricular administration of CART increases TRH mRNA in hypophysiotropic neurons of fasting animals, and CART increases TRH content and release of hypothalamic cells in vitro [163]. These results together with those from Wierup et al. [155] described above provide the basis for future studies of the role played by C-cell secreted CART on thyroid function.

\subsection{Serotonin}

Serotonin or 5-hydroxytryptamine (5-HT) is a biogenic amine synthesized by serotonergic neurons of the CNS, pineal gland and enterochromaffin cells of the gastrointestinal tract of humans and other mammals. Serotonin was isolated for the first time by Rapport et al. in 1948 [164] as a vasoconstrictor plasma agent. In fact, platelet serotonin is released to blood clots contributing to the haemostasis regulation. Serotonin synthesized by enterochromaffin cells is mainly involved in intestinal motility, whereas that synthesized in CNS acts as a neurotransmitter implicated in the regulation of mood, appetite, sleep, memory and learning. Besides, serotonin has antidepressant actions and regulates behaviour, cardiovascular function, muscle contraction, endocrine activity and body temperature [165].

Serotonin is derived from the essential amino acid L-tryptophan. The biosynthetic pathway of serotonin has two enzymatic steps: the first is catalyzed by the enzyme tryptophan- 
hydroxylase (TPH), which converts the tryptophan in 5-hydroxytryptophan (5-HTP), while the second is catalyzed by an amino-acid decarboxylase which removes a carboxyl group from 5-hydroxytryptophan, forming 5-hydroxytryptamine or serotonin. TPH has been shown to exist in two forms: TPH1, found in several tissues, and TPH2, which is a brainspecific isoform [58].

In 1960, Giarman and Freedman confirmed that the pineal gland was the richest site of serotonin in the brain [166]. This discovery suggested the pineal gland as an important site of serotonergic activity. In the pineal gland, much of this serotonin is acetylated and then methylated to yield melatonin during the night. In fact, there are day-night variations in pineal serotonin-content which is low at night, as opposite to plasmatic melatonin, which is low during the day and increases to a peak during the night [167].

Many regulatory factors that control thyroid activity at hypothalamic level have been described. Specifically, serotonin stimulates hypothalamic TRH production, leading to an increase in TSH production from the pituitary. Adequate serotonin production is necessary to maintain thyroid hormone levels. In fact, in depressed patients with low levels of serotonin, treatment with thyroid hormones has increasing effects on selective serotonin reuptake inhibitors (SSRI) [168].

In normal mouse and rat thyroid glands, serotonin is stored as a component of mast-cell granules (see Figure 6C) [169, 170]. Variations on mast-cell exocytosis and serotonin-content seem to be chronobiologically-linked to circadian variations of thyroid activity [169]. In rats, thyrotropin induces a gradual amine release from mast cells within the thyroid gland, where 5-HT stimulates thyroid blood flow and/or vascular permeability [170, 171]. In addition, a 5HT-inactivating transporter (SERT), identical to that of serotonergic neurons has been found in follicular cells of several mammals [172]. Furthermore, follicular cells express specific 5$\mathrm{HT}_{2}$ receptors through which serotonin modulates $\mathrm{TSH}$ response and stimulates thyroid hormone synthesis [58].

Besides mast-cell synthesis, serotonin is also expressed by thyroid C cells of different mammal species, however, as far as we know only sheep, goats, cows, bats and marmosets apparently convert endogenous 5-HTP into 5-HT [173-175]. Mice and rats belong to these many species in which endogenous 5 -HT has not yet been found in adult $\mathrm{C}$ cells, unless the thyroid gland is pretreated with 5-HTP. C cells store serotonin in the same secretory granules as calcitonin [41, 176], where 5-HT is linked to a specific protein called serotoninbinding-protein (SBP) [41, 177-179]. Furthermore, C cells have been proposed as a serotonergic neuron study model since they exhibit some properties of serotonergic neurons, including biosynthesis and storing of serotonin and regulated release and expression of both the 5-HT autoreceptor and the 5-HT transporter [180]. Finally, C cells have been demonstrated to be stimulated by both: extracellular calcium and, in the same way to that described for mast cells, by TSH; these results support the putative regulatory role of the C-cell secreted serotonin [181].

The effects observed on thyroid function could be partly due to extrathyroidal serotonin and, on the other hand, serotonin-synthesis is not a general feature of $C$ cells of every animal 
model. Nevertheless, in accordance to the literature published so far, C-cell secreted serotonin could be, at least for some animal models, considered as a local factor involved in the control of the follicular-cell activity through the hypothalamic-pituitary-thyroid axis.

\subsection{Melatonin}

Melatonin, chemically known as $N$-acetyl-5-methoxytryptamine, is an indoleamine rhythmically secreted by the pineal gland and involved in the regulation of circadian and, sometimes, seasonal rhythms [182]. Although it was originally discovered as a skin-lightening molecule acting on frog and fish melanocytes [183], melatonin is present in all vertebrates and is also produced by bacteria, protozoa, plants, fungi and invertebrates [184, 185].

Pineal melatonin biosynthesis, that takes place during the night, it is activated by norepinephrine through its specific receptor located in the membranes of pinealocytes and consists of four enzymatic reactions. The first two are common to the synthesis of serotonin. Then, serotonin is converted to N-acetylserotonin (NAS) by the enzyme arylalkylamine $\mathrm{N}$ acetyltransferase (AANAT) [186]. NAS is subsequently methylated by hydroxyindole-Omethyltransferase (HIOMT) to form melatonin [187] (see Figure 8).

Melatonin has a wide spectrum of biological activities and it is considered as a pleiotropic compound with important chronobiotic properties. This indoleamine has the capacity to resynchronize circadian rhythms [188-190] and regulate sleep-wake-cycles [191]. Besides playing an important role as a transmitter of photoperiodic information, melatonin has wellcharacterized antioxidant capacities, either, directly as a free-radical neutralizer or, indirectly by enhancing the activity or the expression of antioxidant enzymes [192, 193]. In certain aspects, related to these last activities, there is evidence in the literature that describes potential anti-aging and anticarcinogenic effects for melatonin [194].

Action mechanisms of melatonin are very varied. In this respect, this hormone can bind to specific G-protein coupled membrane receptors, of which there are two subtypes in mammals: melatonin-receptor $1 \mathrm{a}\left(\mathrm{MT}_{1}\right)$ and melatonin-receptor $1 \mathrm{~b}\left(\mathrm{MT}_{2}\right)$ [195]. $\mathrm{MT}_{1}$ and $\mathrm{MT}_{2}$ possess high-affinity binding sites for melatonin and are widely distributed in CNS and in a wide-spectrum of peripheral tissues [196, 197]. Furthermore, and in addition to its abilities as a free-radical scavenger described above, melatonin has been described to interact with nuclear receptors $[198,199]$ as well as cytoplasmic proteins such as calmodulin and protein kinase $\mathrm{C}$.

Since its discovery, melatonin had been considered an exclusive hormone of the pineal gland. However, numerous published studies have changed this view, describing many extrapineal tissues, such as retina [200], Harderian gland [201], gut [202], ovary [203, 204], immune system [205, 206], skin [207], and testes [208], as melatonin synthesizers.

Moreover, melatonin has also been found in the rat thyroid-gland, specifically, immunopositive C cells for melatonin have been detected [45]. Furthermore, our research group has recently demonstrated endogenous melatonin biosynthesis by rat thyroid $C$ cells through the expression of the two key melatonin biosynthetic enzymes, AANAT and 
HIOMT and, moreover, melatonin membrane receptors have also been found in the rat thyroid gland, specifically, on follicular-cell and C-cell membranes [209] (see Figure 8).
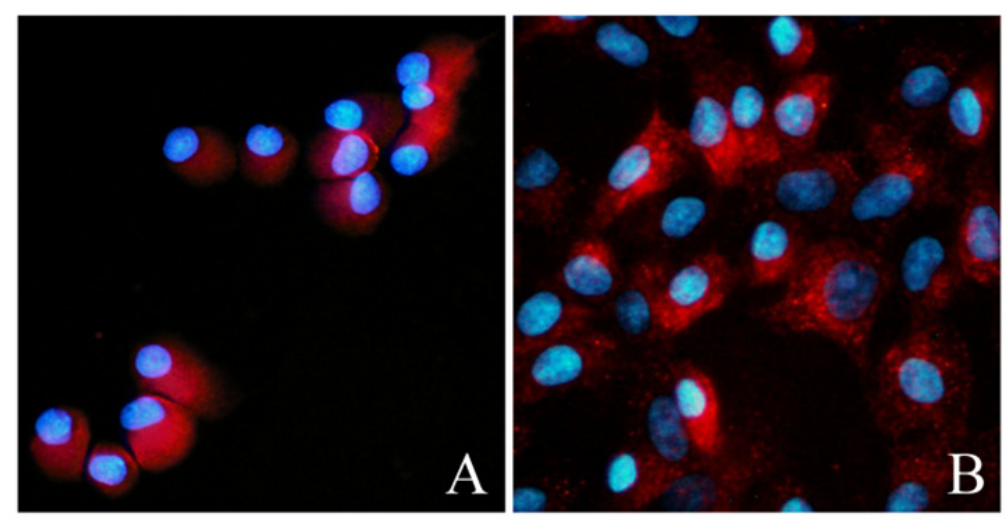

Figure 8. Immunolocalization of AANAT in a rat C-cell line (CA77) (A), and melatonin receptor (MT1) in a follicular-cell line (PC-Cl3) (B) by immunofluorescence.

Many effects of melatonin on the thyroid gland have been described so far in the literature. In rodents, high doses of melatonin inhibit basal and TSH-stimulated mitotic activity of thyroid follicular cells in vivo and in primary culture [210]. Besides, melatonin has a direct inhibitory effect on $\mathrm{T}_{4}$ secretion and, also, depresses the response of the thyroid to TSH [211]. Furthermore, melatonin plays a protective role against oxidative stress in the rat thyroid gland [212-214].

As regard to the latter, reactive oxygen species (ROS) are deeply involved in cellular processes of the thyroid gland. Follicular cells are subjected to high oxidative stress since they require hydrogen peroxide $\left(\mathrm{H}_{2} \mathrm{O}_{2}\right)$ for thyroid hormones biosynthesis and moreover, a large number of diseases associated with $\mathrm{H}_{2} \mathrm{O}_{2}$ accumulation in the thyroid gland have been described. For example, $\mathrm{H}_{2} \mathrm{O}_{2}$ participates in the Wolff-Chaikoff's effect and in hypothyroidism caused by iodine excess in the thyroid [213]. Melatonin has been suggested to be able to directly scavenge $\mathrm{H}_{2} \mathrm{O}_{2}$ [215]; in accordance to this last point melatonin synthesized by $\mathrm{C}$ cells might play a role in thyroid antioxidant defense against oxidative stress. Endogenous synthesized intrathyroidal melatonin could, thus, be a kind of local regulator that could regulate redox homeostasis and modulate thyroid function [216].

\subsection{Other C-cell secreted peptides}

The data presented here describe, according to our criteria, the most significant regulatory factors produced by $\mathrm{C}$ cells and their effects and pathways involved on follicular-cell activity according to the literature. Nevertheless, as illustrated in the present review, the list of C-cell secreted peptides and their putative paracrine functions on follicular cells is constantly being enlarged. 
In addition to those described along the present chapter, and despite the fact that there is still limited evidence in the literature, there is a small group of regulatory factors such as bombesin/GRP, CCK (cholecystokinin) and helodermin, that should be observed as potential new candidates for thyroid local-modulators.

Bombesin/GRP (gastrin-releasing peptide) was first described as being expressed by neoplastic C cells from MTCs by the group of Kameya et al. In 1983 [217]. Moreover, Ahren in 1989 [57] confirmed that GRP had the capacity to stimulate both basal and TSHstimulated thyroid hormone secretion in mice. Furthermore, differences in GRP synthesis among developing thyroid $C$ cells, normal adult $C$ cells, and neoplastic $C$ cells led Sunday et al [32] to hypothesize that C-cell GRP gene-expression might play a role in both normal and neoplastic growth processes.

In the case of CCK, its expression in C cells was described by Arias et al. in rat thyroid gland [42]. Recently, its receptor CCK2R, which is shared with gastrin, has been described to be expressed at different intensities in normal and malignant $C$ cells by Blakër et al. [218]. No additional data has been published with regard to the putative functional role of CCK signalling in thyroid, however, there are initial encouraging therapeutic results with the use of CCK/Gastrin R2-binding peptides in patients with MTC [219, 220].

The last factor from this "other" group is the amidated peptide helodermin. Originally isolated from Heloderma suspectum [221, 222], helodermin was described to be expressed by rat C cells by Grunditz et al. in 1999 [35]. Furthermore, these authors reported dose and time course experiments which showed a consistent stimulatory effect of helodermin on thyroid hormone synthesis.

Although some of these data seemed to have well-characterized new pathways for C-cell and thyrocytes interrelationships, surprisingly no further studies that illustrated new insights for this evidence have been reported so far. Therefore, to our knowledge, future studies are still necessary to finally clarify their involvement in thyroid function and homeostasis.

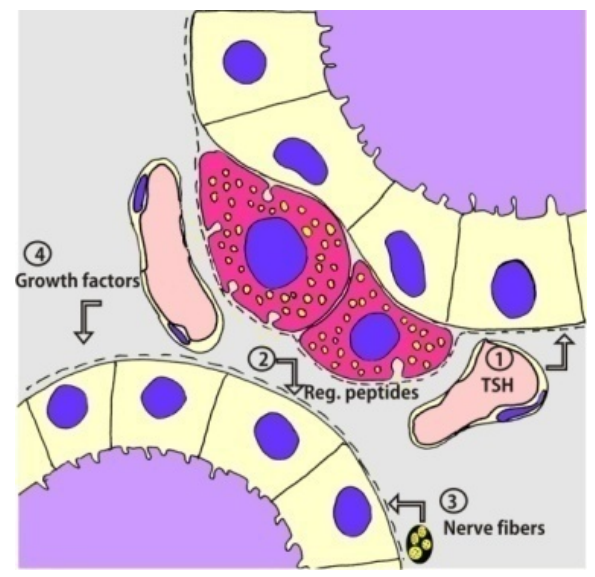

Figure 9. Schematic diagram of the different mechanisms of regulation of the synthesis of thyroid hormones by follicular cells. 


\section{Conclusion}

In conclusion, according to the data published so far in the literature and revised through this chapter, a number of regulatory factors are produced at thyroid level by $\mathrm{C}$ cells and have direct effects on follicular-cell activity at both proliferative and thyroid hormone synthesis levels (Figure 9). These new paracrine regulatory mechanisms would justify, from a phylogenetic point of view, the parafollicular localization of $C$ cells in mammals and might open new molecular approaches for the treatment of human thyroid disease.

\section{Author details}

José María Fernández-Santos, Jesús Morillo-Bernal, Rocío García-Marín, José Carmelo Utrilla and Inés Martín-Lacave* Department of Cytology and Histology. School of Medicine, University of Seville, Spain

\section{Acknowledgement}

This work was supported by grants from the Consejería de Innovación, Ciencia y Empresa, Junta de Andalucía, Spain (refs. CTS-439/2009 and P08-CVI-03598).The authors thank Mr. John Brown for the corrections of the English language.

\section{References}

[1] Ahren B (1991) Regulatory peptides in the thyroid gland -a review on their localization and function. Acta Endocrinol (Copenh). 124: 225-32.

[2] Eggo MC, Quiney VM, Campbell S (2003) Local factors regulating growth and function of human thyroid cells in vitro and in vivo. Mol Cell Endocrinol. 213: 47-58.

[3] Biddinger PW, Ray M (1993) Distribution of C cells in the normal and diseased thyroid gland. Pathol Annu. 28 Pt 1: 205-29.

[4] Conde E, Moreno AM, Martin-Lacave I, Fernandez A, Galera H (1992) Immunocytochemical study of the ultimobranchial tubule in Wistar rats. Anat Histol Embryol. 21: 94-100.

[5] Martin-Lacave I, Conde E, Moreno A, Utrilla JC, Galera H (1992) Evidence of the occurrence of calcitonin cells in the ultimobranchial follicle of the rat postnatal thyroid. Acta Anat (Basel). 144: 93-6.

[6] Harach HR (1988) Solid cell nests of the thyroid. J Pathol. 155: 191-200.

[7] Sugiyama S (1971) The embryology of the human thyroid gland including ultimobranchial body and others related. Ergeb Anat Entwicklungsgesch. 44: 3-111.

[8] Copp DH, Cockcroft DW, Kueh Y (1967) Calcitonin from ultimobranchial glands of dogfish and chickens. Science. 158: 924-5.

\footnotetext{
${ }^{*}$ Corresponding Authors
} 
[9] Le Douarin N, Le Lièvre C (1970). [Demonstration of neural origin of calcitonin cells of ultimobranchial body of chick embryo C R Acad Sci Hebd Seances Acad Sci D. 270:2857-60.

[10] Kameda Y, Nishimaki T, Chisaka O, Iseki S, Sucov HM (2007) Expression of the epithelial marker E-cadherin by thyroid $\mathrm{C}$ cells and their precursors during murine development. J Histochem Cytochem. 55: 1075-88.

[11] Pearse AG (1966) Common cytochemical properties of cells producing polypeptide hormones, with particular reference to calcitonin and the thyroid C cells. Vet Rec. 79: 587-90.

[12] Pearse AG (1977) The diffuse neuroendocrine system and the APUD concept: related "endocrine" peptides in brain, intestine, pituitary, placenta, and anuran cutaneous glands. Med Biol. 55: 115-25.

[13] DeLellis RA, Dayal Y (1992) Neuroendocrine System. In: Sterberg SS, Editor. Histology for Pathologists. New York: Reven Press. p. 347-62.

[14] Conde E, Martin-Lacave I, Utrilla JC, Gonzalez-Campora R, Galera-Davidson H (1995) Postnatal variations in the number and size of C-cells in the rat thyroid gland. Cell Tissue Res. 280: 659-63.

[15] Wolfe HJ, Voelkel EF, Tashjian AH, Jr. (1974) Distribution of calcitonin-containing cells in the normal adult human thyroid gland: a correlation of morphology with peptide content. J Clin Endocrinol Metab. 38: 688-94.

[16] Gibson WG, Peng TC, Croker BP (1982) Age-associated C-cell hyperplasia in the human thyroid. Am J Pathol. 106: 388-93.

[17] Kameda Y (1971) The occurrence and distribution of the parafollicular cells in the thyroid, parathyroid IV and thymus IV in some mammals. Arch Histol Jpn. 33: 283-99.

[18] Martin-Lacave I, Conde E, Montero C, Galera-Davidson H (1992) Quantitative changes in the frequency and distribution of the C-cell population in the rat thyroid gland with age. Cell Tissue Res. 270: 73-7.

[19] McMillan PJ, Heidbuchel U, Vollrath L (1985) Number and size of rat thyroid C cells: no effect of pinealectomy. Anat Rec. 212: 167-71.

[20] Kalisnik M, Vraspir-Porenta O, Kham-Lindtner T, Logonder-Mlinsek M, Pajer Z, Stiblar-Martincic D, et al. (1988) The interdependence of the follicular, parafollicular, and mast cells in the mammalian thyroid gland: a review and a synthesis. Am J Anat. 183: $148-57$.

[21] Roediger WE (1975) The oxyphil and C cells of the human thyroid gland. A cytochemical and histopathologic review. Cancer. 36: 1758-70.

[22] Lloyd RV, Sisson JC, Marangos PJ (1983) Calcitonin, carcinoembryonic antigen and neuron-specific enolase in medullary thyroid carcinoma. Cancer. 51: 2234-9.

[23] Thompson RJ, Doran JF, Jackson P, Dhillon AP, Rode J (1983) PGP 9.5--a new marker for vertebrate neurons and neuroendocrine cells. Brain Res. 278: 224-8.

[24] O'Connor DT, Burton D, Deftos LJ (1983) Chromogranin A: immunohistology reveals its universal occurrence in normal polypeptide hormone producing endocrine glands. Life Sci. 33: 1657-63. 
[25] Weiler R, Cidon S, Gershon MD, Tamir H, Hogue-Angeletti R, Winkler H (1989) Adrenal chromaffin granules and secretory granules from thyroid parafollicular cells have several common antigens. FEBS Lett. 257: 457-9.

[26] Marcinkiewicz M, Benjannet S, Falgueyret JP, Seidah NG, Schurch W, Verdy M, et al. (1988) Identification and localization of 7B2 protein in human, porcine, and rat thyroid gland and in human medullary carcinoma. Endocrinology. 123: 866-73.

[27] Schmid KW, Kunk B, Kirchmair R, Totsch M, Bocker W, Fischer-Colbrie R (1995) Immunohistochemical detection of secretoneurin, a novel neuropeptide endoproteolytically processed from secretogranin II, in normal human endocrine and neuronal tissues. Histochem J. 27: 473-81.

[28] Tomita T (1997) Matrix metalloproteinases and tissue inhibitors of metalloproteinases in thyroid C-cells and medullary thyroid carcinomas. Histopathology. 31: 150-6.

[29] Kurabuchi S, Tanaka S (2002) Immunocytochemical localization of prohormone convertases PC1 and PC2 in the mouse thyroid gland and respiratory tract. J Histochem Cytochem. 50: 903-9.

[30] Sabate MI, Stolarsky LS, Polak JM, Bloom SR, Varndell IM, Ghatei MA, et al. (1985) Regulation of neuroendocrine gene expression by alternative RNA processing. Colocalization of calcitonin and calcitonin gene-related peptide in thyroid C-cells. J Biol Chem. 260: 2589-92.

[31] Ali-Rachedi A, Varndell IM, Facer P, Hillyard CJ, Craig RK, MacIntyre I, et al. (1983) Immunocytochemical localisation of katacalcin, a calcium-lowering hormone cleaved from the human calcitonin precursor. J Clin Endocrinol Metab. 57: 680-2.

[32] Sunday ME, Wolfe HJ, Roos BA, Chin WW, Spindel ER (1988) Gastrin-releasing peptide gene expression in developing, hyperplastic, and neoplastic human thyroid C-cells. Endocrinology. 122: 1551-8.

[33] Kameda Y, Oyama H, Endoh M, Horino M (1982) Somatostatin immunoreactive C cells in thyroid glands from various mammalian species. Anat Rec. 204: 161-70.

[34] Domin J, Al-Madani AM, Desperbasques M, Bishop AE, Polak JM, Bloom SR (1990) Neuromedin U-like immunoreactivity in the thyroid gland of the rat. Cell Tissue Res. 260: 131-5.

[35] Grunditz T, Persson P, Hakanson R, Absood A, Bottcher G, Rerup C, et al. (1989) Helodermin-like peptides in thyroid $C$ cells: stimulation of thyroid hormone secretion and suppression of calcium incorporation into bone. Proc Natl Acad Sci U S A. 86: 135761.

[36] Gkonos PJ, Tavianini MA, Liu CC, Roos BA (1989) Thyrotropin-releasing hormone gene expression in normal thyroid parafollicular cells. Mol Endocrinol. 3: 2101-9.

[37] Wierup N, Kuhar M, Nilsson BO, Mulder H, Ekblad E, Sundler F (2004) Cocaine- and amphetamine-regulated transcript (CART) is expressed in several islet cell types during rat development. J Histochem Cytochem. 52: 169-77.

[38] Raghay K, Garcia-Caballero T, Nogueiras R, Morel G, Beiras A, Dieguez C, et al. (2006) Ghrelin localization in rat and human thyroid and parathyroid glands and tumours. Histochem Cell Biol. 125: 239-46. 
[39] Bussolati G, Pearse AG (1967) Immunofluorescent localization of calcitonin in the 'C' cells of pig and dog thyroid. The Journal of endocrinology. 37: 205-9.

[40] Kameda Y (1987) Localization of immunoreactive calcitonin gene-related peptide in thyroid C cells from various mammalian species. Anat Rec. 219: 204-12.

[41] Barasch JM, Tamir H, Nunez EA, Gershon MD (1987) Serotonin-storing secretory granules from thyroid parafollicular cells. J Neurosci. 7: 4017-33.

[42] Arias J, Scopsi L, Fischer JA, Larsson LI (1989) Light- and electron-microscopical localization of calcitonin, calcitonin gene-related peptide, somatostatin and C-terminal gastrin/cholecystokinin immunoreactivities in rat thyroid. Histochemistry. 91: 265-72.

[43] Cohen R, Delehaye MC, Minvielle S, Segond N, Taboulet J, Noel M, et al. (1992) CCP II: a novel calcitonin carboxy terminal peptide is expressed in normal thyroid tissue. Biochem Biophys Res Commun. 185: 330-4.

[44] Okada H, Capen CC, Rosol TJ (1995) Immunohistochemical demonstration of parathyroid hormone-related protein in thyroid gland of sheep. Vet Pathol. 32: 315-7.

[45] Kvetnoy IM (1999) Extrapineal melatonin: location and role within diffuse neuroendocrine system. Histochem J. 31: 1-12.

[46] Scopsi L, Pilotti S, Rilke F (1990) Immunocytochemical localization and identification of members of the pancreatic polypeptide (PP)-fold family in human thyroid C cells and medullary carcinomas. Regul Pept.30: 89-104.

[47] Kosowicz J, Miskowiak B, Konwerska A, Tortorella C, Nussdorfer GG, Malendowicz LK (2003) Tissue distribution of pneumadin immunoreactivity in the rat. Peptides. 24: $215-20$.

[48] Xu L, Zhong F, Guo FF, Zhao WJ, Sun XR, Wei XF (2008) [Expression of motilin and its precursor mRNA in normal parenchyma, benign and malignant tumors of human thyroid]. Zhonghua Bing Li Xue Za Zhi. 37: 243-9.

[49] Matsuo T, Yamaguchi H, Kageyama H, Sasaki K, Shioda S, Minamino N, et al. (2010) Localization of neuroendocrine regulatory peptide- 1 and-2 in human tissues. Regul Pept. 163: 43-8.

[50] Christensen L, Johansen N, Jensen BA, Clemmensen I (1987) Immunohistochemical localization of a novel, human plasma protein, tetranectin, in human endocrine tissues. Histochemistry. 87: 195-9.

[51] Kodama T, Fujino M, Endo Y, Obara T, Fujimoto Y, Oda T, et al. (1980) Identification of carcinoembryonic antigen in the C-cell of the normal thyroid. Cancer. 45: 98-101.

[52] Braas KM, Harakall SA, Ouafik L, Eipper BA, May V (1992) Expression of peptidylglycine alpha-amidating monooxygenase: an in situ hybridization and immunocytochemical study. Endocrinology. 130: 2778-88.

[53] Nishiyama I, Ogiso M, Oota T, Kimura T, Seki T (1996) Developmental change in expression of highly polysialylated neural cell adhesion molecule in C-cells in rat thyroid gland. Anat Embryol (Berl). 194: 419-26.

[54] Darlington DN, Schiller MR, Mains RE, Eipper BA (1997) The expression of regulated endocrine-specific protein of $18 \mathrm{kDa}$ in peptidergic cells of rat peripheral endocrine tissues and in blood. J Endocrinol. 155: 329-41. 
[55] Martin-Lacave I, Utrilla JC (2000) Expression of a neu/c-erbB-2-like product in neuroendocrine cells of mammals. Histol Histopathol. 15: 1027-33.

[56] Sawicki B (1995) Evaluation of the role of mammalian thyroid parafollicular cells. Acta Histochem. 97: 389-99.

[57] Ahren B (1989) Effects of gastrin-releasing peptide on basal and stimulated thyroid hormone secretion in the mouse. Acta Endocrinol (Copenh). 120: 245-9.

[58] Tamir H, Hsiung SC, Yu PY, Liu KP, Adlersberg M, Nunez EA, et al. (1992) Serotonergic signalling between thyroid cells: protein kinase $\mathrm{C}$ and 5-HT2 receptors in the secretion and action of serotonin. Synapse. 12: 155-68.

[59] Forssell-Aronsson EB, Nilsson O, Bejegard SA, Kolby L, Bernhardt P, Molne J, et al. (2000) 111In-DTPA-D-Phe1-octreotide binding and somatostatin receptor subtypes in thyroid tumors. J Nucl Med. 41: 636-42.

[60] De Miguel M, Fernandez-Santos JM, Utrilla JC, Carrillo-Vico A, Borrero J, Conde E, et al. (2005) Thyrotropin-releasing hormone receptor expression in thyroid follicular cells: a new paracrine role of C-cells? Histol Histopathol. 20: 713-8.

[61] Albores-Saavedra J, Monforte H, Nadji M, Morales AR (1988) C-cell hyperplasia in thyroid tissue adjacent to follicular cell tumors. Hum Pathol. 19: 795-9.

[62] Scopsi L, Di Palma S, Ferrari C, Holst JJ, Rehfeld JF, Rilke F (1991) C-cell hyperplasia accompanying thyroid diseases other than medullary carcinoma: an immunocytochemical study by means of antibodies to calcitonin and somatostatin. Mod Pathol. 4: 297-304.

[63] Martin-Lacave I, Borrero MJ, Utrilla JC, Fernandez-Santos JM, de Miguel M, Morillo J, et al. (2009) C cells evolve at the same rhythm as follicular cells when thyroidal status changes in rats. J Anat. 214: 301-9.

[64] Morillo-Bernal J, Fernandez-Santos JM, Utrilla JC, de Miguel M, Garcia-Marin R, Martin-Lacave I (2009) Functional expression of the thyrotropin receptor in C cells: new insights into their involvement in the hypothalamic-pituitary-thyroid axis. J Anat. 215: 150-8.

[65] Raue F, Zink A, Scherubl H (1993) Regulation of calcitonin secretion in vitro. Horm Metab Res. 25: 473-6.

[66] Suzuki K, Lavaroni S, Mori A, Okajima F, Kimura S, Katoh R, et al. (1998) Thyroid transcription factor 1 is calcium modulated and coordinately regulates genes involved in calcium homeostasis in C cells. Mol Cell Biol. 18: 7410-22.

[67] Copp DH, Cameron EC (1961) Demonstration of a hypocalcemic factor (calcitonin) in commercial parathyroid extract. Science. 134: 2038.

[68] Kumar MA, Foster GV, MacIntyre I (1963) Further Evidence for Calcitonin. A RapidActing Hormone Which Lowers Plasma-Calcium. Lancet. 2: 480-2.

[69] Pondel M (2000) Calcitonin and calcitonin receptors: bone and beyond. Int J Exp Pathol. 81: 405-22.

[70] Perez Cano R, Girgis SI, Galan Galan F, MacIntyre I (1982) Identification of both human and salmon calcitonin-like molecules in birds suggesting the existence of two calcitonin genes. J Endocrinol. 92: 351-5. 
[71] Perez Cano R, Girgis SI, MacIntyre I (1982) Further evidence for calcitonin gene duplication: the identification of two different calcitonins in a fish, a reptile and two mammals. Acta Endocrinol (Copenh). 100: 256-61.

[72] Inzerillo AM, Zaidi M, Huang CL (2002) Calcitonin: the other thyroid hormone. Thyroid. 12: 791-8.

[73] Amara SG, Jonas V, Rosenfeld MG, Ong ES, Evans RM (1982) Alternative RNA processing in calcitonin gene expression generates mRNAs encoding different polypeptide products. Nature. 298: 240-4.

[74] Rosenfeld MG, Mermod JJ, Amara SG, Swanson LW, Sawchenko PE, Rivier J, et al. (1983) Production of a novel neuropeptide encoded by the calcitonin gene via tissuespecific RNA processing. Nature. 304: 129-35.

[75] Fischer JA, Tobler PH, Henke H, Tschopp FA (1983) Salmon and human calcitonin-like peptides coexist in the human thyroid and brain. J Clin Endocrinol Metab. 57: 1314-6.

[76] Lin HY, Harris TL, Flannery MS, Aruffo A, Kaji EH, Gorn A, et al. (1991) Expression cloning of an adenylate cyclase-coupled calcitonin receptor. Science. 254: 1022-4.

[77] Pondel MD, Jagger C, Hebden C, Partington G, Mould R (2002) Transcriptional regulation of the calcitonin receptor gene. Biochem Soc Trans. 30: 423-7.

[78] Gorn AH, Rudolph SM, Flannery MR, Morton CC, Weremowicz S, Wang TZ, et al. (1995) Expression of two human skeletal calcitonin receptor isoforms cloned from a giant cell tumor of bone. The first intracellular domain modulates ligand binding and signal transduction. J Clin Invest. 95: 2680-91.

[79] Frendo JL, Delage-Mourroux R, Cohen R, Pichaud F, Pidoux E, Guliana JM, et al. (1998) Calcitonin receptor mRNA is expressed in human medullary thyroid carcinoma. Thyroid. 8: 141-7.

[80] Breimer LH, MacIntyre I, Zaidi M (1988) Peptides from the calcitonin genes: molecular genetics, structure and function. Biochem J. 255: 377-90.

[81] Seifert H, Sawchenko P, Chesnut J, Rivier J, Vale W, Pandol SJ (1985) Receptor for calcitonin gene-related peptide: binding to exocrine pancreas mediates biological actions. Am J Physiol. 249: G147-51.

[82] Zaidi M, Chambers TJ, Bevis PJ, Beacham JL, Gaines Das RE, MacIntyre I (1988) Effects of peptides from the calcitonin genes on bone and bone cells. Q J Exp Physiol. 73: 47185.

[83] Ahren B (1989) Effects of calcitonin, katacalcin, and calcitonin gene-related peptide on basal and TSH-stimulated thyroid hormone secretion in the mouse. Acta Physiol Scand. 135: 133-7.

[84] Brazeau P, Vale W, Burgus R, Ling N, Butcher M, Rivier J, et al. (1973) Hypothalamic polypeptide that inhibits the secretion of immunoreactive pituitary growth hormone. Science. 179: 77-9.

[85] Patel YC (1999) Somatostatin and its receptor family. Front Neuroendocrinol. 20: 157-98.

[86] Reichlin S (1983) Somatostatin. N Engl J Med. 309: 1495-501.

[87] Reichlin S (1983) Somatostatin (second of two parts). N Engl J Med. 309: 1556-63.

[88] Epelbaum J, Dournaud P, Fodor M, Viollet C (1994) The neurobiology of somatostatin. Crit Rev Neurobiol. 8: 25-44. 
[89] Aguila MC, Rodriguez AM, Aguila-Mansilla HN, Lee WT (1996) Somatostatin antisense oligodeoxynucleotide-mediated stimulation of lymphocyte proliferation in culture. Endocrinology. 137: 1585-90.

[90] Karalis K, Mastorakos G, Chrousos GP, Tolis G (1994) Somatostatin analogues suppress the inflammatory reaction in vivo. J Clin Invest. 93: 2000-6.

[91] Elliott DE, Blum AM, Li J, Metwali A, Weinstock JV (1998) Preprosomatostatin messenger RNA is expressed by inflammatory cells and induced by inflammatory mediators and cytokines. J Immunol. 160: 3997-4003.

[92] Patel YC, Srikant CB (1997) Somatostatin receptors. Trends Endocrinol Metab. 8: 398405.

[93] Raynor K, Coy DC, Reisine T (1992) Analogues of somatostatin bind selectively to brain somatostatin receptor subtypes. J Neurochem. 59: 1241-50.

[94] Reisine T, Woulfe D, Raynor K, Kong H, Heerding J, Hines J, et al. (1995) Interaction of somatostatin receptors with $\mathrm{G}$ proteins and cellular effector systems. Ciba Foundation symposium. 190: 160-7; discussion 7-70.

[95] Van Noorden S, Polak JM, Pearse AG (1977) Single cellular origin of somatostatin and calcitonin in the rat thyroid gland. Histochemistry. 53: 243-7.

[96] Alumets J, Hakanson R, Lundqvist G, Sundler F, Thorell J (1980) Ontogeny and ultrastructure of somatostatin and calcitonin cells in the thyroid gland of the rat. Cell Tissue Res. 206: 193-201.

[97] Zabel M, Surdyk J, Biela-Jacek I (1987) Immunocytochemical studies on thyroid parafollicular cells in postnatal development of the rat. Acta Anat (Basel). 130: 251-6.

[98] Fierabracci A, Castagna M, Baschieri L (1993) Calcitonin and somatostatin containing C cells in rat and human thyroid. Immunohistochemical study by a double-staining method. Pathologica. 85: 467-74.

[99] Ahren B, Hedner P, Melander A, Westgren U (1977) Inhibition by somatostatin of mouse thyroid activity following stimulation by thyrotrophin, isoprenaline and dibutyryl cyclic-AMP Acta Endocrinol (Copenh). 86: 323-9.

[100] Loos U, Raptis S, Birk J, Escobar-Jimenez F, Meyer G, Rothenbuchner G, et al. (1978) Inhibition of TSH-stimulated radioiodine turnover and release of T4 and T3 in vivo by somatostatin. Metabolism. 27: 1269-73.

[101] Siperstein AE, Levin KE, Gum ET, Clark OH (1992) Effect of somatostatin on adenylate cyclase activity in normal and neoplastic thyroid tissue. World J Surg. 16: 555-60.

[102] Brandi ML, Toccafondi R (1985) Neuropeptidergic control of cyclic AMP accumulation in human thyroid cell. Peptides. 6: 641-4.

[103] degli Uberti EC, Hanau S, Rossi R, Piva R, Margutti A, Trasforini G, et al. (1991) Somatostatin reduces $3 \mathrm{H}$-thymidine incorporation and c-myc, but not thyroglobulin ribonucleic acid levels in human thyroid follicular cells in vitro. J Clin Endocrinol Metab. 72: 1364-71.

[104] Lechan RM, Wu P, Jackson IM (1986) Immunolocalization of the thyrotropin-releasing hormone prohormone in the rat central nervous system. Endocrinology. 119: 1210-6.

[105] Lechan RM, Wu P, Jackson IM, Wolf H, Cooperman S, Mandel G, et al. (1986) Thyrotropin-releasing hormone precursor: characterization in rat brain. Science. 231: 159-61. 
[106] de la Pena P, Delgado LM, del Camino D, Barros F (1992) Two isoforms of the thyrotropin-releasing hormone receptor generated by alternative splicing have indistinguishable functional properties. J Biol Chem. 267: 25703-8.

[107] O'Dowd BF, Lee DK, Huang W, Nguyen T, Cheng R, Liu Y, et al. (2000) TRH-R2 exhibits similar binding and acute signaling but distinct regulation and anatomic distribution compared with TRH-R1. Mol Endocrinol. 14: 183-93.

[108] Cao J, O'Donnell D, Vu H, Payza K, Pou C, Godbout C, et al. (1998) Cloning and characterization of a cDNA encoding a novel subtype of rat thyrotropin-releasing hormone receptor. J Biol Chem. 273: 32281-7.

[109] Deflorian F, Engel S, Colson AO, Raaka BM, Gershengorn MC, Costanzi S (2008) Understanding the structural and functional differences between mouse thyrotropinreleasing hormone receptors 1 and 2. Proteins. 71: 783-94.

[110] Griffiths EC (1985) Thyrotrophin releasing hormone: endocrine and central effects. Psychoneuroendocrinology. 10: 225-35.

[111] Sun Y, Zupan B, Raaka BM, Toth M, Gershengorn MC (2009) TRH-receptor-type-2deficient mice are euthyroid and exhibit increased depression and reduced anxiety phenotypes. Neuropsychopharmacology. 34: 1601-8.

[112] Satoh T, Feng P, Kim UJ, Wilber JF (1994) Identification of thyrotropin-releasing hormone receptor in the rat testis. Neuropeptides. 27: 195-202.

[113] Mellado M, Fernandez-Agullo T, Rodriguez-Frade JM, San Frutos MG, de la Pena P, Martinez AC, et al. (1999) Expression analysis of the thyrotropin-releasing hormone receptor (TRHR) in the immune system using agonist anti-TRHR monoclonal antibodies. FEBS Lett. 451: 308-14.

[114] Morley JE (1979) Extrahypothalamic thyrotropin releasing hormone (TRH) -- its distribution and its functions. Life Sci. 25: 1539-50.

[115] Pekary AE, Reeve JR, Jr., Smith VP (1986) Evidence for thyrotropin-releasing hormone (TRH) biosynthesis in rat prostate. Life Sci. 39: 2565-70.

[116] Iversen E, Weeke J, Laurberg P (1984) TRH immunoreactivity in the thyroid gland. Scand J Clin Lab Invest. 44: 703-9.

[117] Montagne JJ, Ladram A, Grouselle D, Nicolas P, Bulant M (1997) Thyrotropinreleasing hormone immunoreactivity in rat adrenal tissue is localized in mast cells. J Histochem Cytochem. 45: 1623-7.

[118] Bacova Z, Baqi L, Benacka O, Payer J, Krizanova O, Zeman M, et al. (2006) Thyrotropin-releasing hormone in rat heart: effect of swelling, angiotensin II and renin gene. Acta Physiol (Oxf). 187: 313-9.

[119] Yamada M, Shibusawa N, Ishii S, Horiguchi K, Umezawa R, Hashimoto K, et al. (2006) Prolactin secretion in mice with thyrotropin-releasing hormone deficiency. Endocrinology. 147: 2591-6.

[120] Delbeke D, Van Sande J, Cochaux P, Decoster C, Dumont JE (1983) Effect of thyrotropin-releasing hormone on dog thyroid in vitro. Biochim Biophys Acta. 761: 2628.

[121] Iversen E, Laurberg P (1985) Thyrotrophin-releasing hormone (TRH) and hormone secretion from the follicular and C-cells of perfused dog thyroid lobes. Acta Endocrinol (Copenh). 109: 499-504. 
[122] Rausell V, Fraser HM, Tobaruela M, del Rio-Garcia J, Smyth DG (1999) Identification of the TRH-like peptides pGlu-Glu-Pro amide and pGlu-Phe-Pro amide in rat thyroid: regulation by thyroid status. Reg Pept. 81: 55-60.

[123] Raspe E, Laurent E, Andry G, Dumont JE (1991) ATP, bradykinin, TRH and TSH activate the $\mathrm{Ca}(2+)$-phosphatidylinositol cascade of human thyrocytes in primary culture. Mol Cell Endocrinol. 81: 175-83.

[124] Sato A, Yamada T, Aizawa T, Ichikawa K, Komiya I, Takasu N, et al. (1995) Effect of thyrotropin-releasing hormone on serum thyroid hormones: a study in the patients with untreated and treated Graves' disease and subacute thyroiditis. J Clin Endocrinol Metab. 80: 2173-7.

[125] Kojima M, Hosoda H, Date Y, Nakazato M, Matsuo H, Kangawa K (1999) Ghrelin is a growth-hormone-releasing acylated peptide from stomach. Nature. 402: 656-60.

[126] Arvat E, Maccario M, Di Vito L, Broglio F, Benso A, Gottero C, et al. (2001) Endocrine activities of ghrelin, a natural growth hormone secretagogue (GHS), in humans: comparison and interactions with hexarelin, a nonnatural peptidyl GHS, and GHreleasing hormone. J Clin Endocrinol Metab. 86: 1169-74.

[127] Korbonits M, Goldstone AP, Gueorguiev M, Grossman AB (2004) Ghrelin--a hormone with multiple functions. Front Neuroendocrinol. 25: 27-68.

[128] Van der Lely AJ, Tschop M, Heiman ML, Ghigo E (2004) Biological, physiological, pathophysiological, and pharmacological aspects of ghrelin. Endocr Rev. 25: 426-57.

[129] Caminos JE, Tena-Sempere M, Gaytan F, Sanchez-Criado JE, Barreiro ML, Nogueiras R, et al. (2003) Expression of ghrelin in the cyclic and pregnant rat ovary. Endocrinology. 144: 1594-602.

[130] Fernandez-Fernandez R, Tena-Sempere M, Aguilar E, Pinilla L (2004) Ghrelin effects on gonadotropin secretion in male and female rats. Neurosci Lett. 362: 103-7.

[131] Kluge M, Schussler P, Uhr M, Yassouridis A, Steiger A (2007) Ghrelin suppresses secretion of luteinizing hormone in humans. J Clin Endocrinol Metab. 92: 3202-5.

[132] Date Y, Kojima M, Hosoda H, Sawaguchi A, Mondal MS, Suganuma T, et al. (2000) Ghrelin, a novel growth hormone-releasing acylated peptide, is synthesized in a distinct endocrine cell type in the gastrointestinal tracts of rats and humans. Endocrinology. 141: 4255-61.

[133] Cummings DE, Purnell JQ, Frayo RS, Schmidova K, Wisse BE, Weigle DS (2001) A preprandial rise in plasma ghrelin levels suggests a role in meal initiation in humans. Diabetes. 50: 1714-9.

[134] Bagnasco M, Kalra PS, Kalra SP (2002) Ghrelin and leptin pulse discharge in fed and fasted rats. Endocrinology. 143: 726-9.

[135] Raghay K, Garcia-Caballero T, Bravo S, Alvarez CV, Gonzalez R, Dieguez C, et al. (2008) Ghrelin localization in the medulla of rat and human adrenal gland and in pheochromocytomas. Histol Histopathol. 23: 57-65.

[136] Morillo-Bernal J, Fernandez-Santos JM, De Miguel M, Garcia-Marin R, GordilloMartinez F, Diaz-Parrado E, et al. (2011) Ghrelin potentiates TSH-induced expression of the thyroid tissue-specific genes thyroglobulin, thyroperoxidase and sodium-iodine symporter, in rat PC-Cl3 Cells. Peptides. 32:2333-9 
[137] Katergari SA, Milousis A, Pagonopoulou O, Asimakopoulos B, Nikolettos NK (2008) Ghrelin in pathological conditions. Endocr J. 55: 439-53.

[138] Kanamoto N, Akamizu T, Hosoda H, Hataya Y, Ariyasu H, Takaya K, et al. (2001) Substantial production of ghrelin by a human medullary thyroid carcinoma cell line. J Clin Endocrinol Metab. 86: 4984-90.

[139] Gnanapavan S, Kola B, Bustin SA, Morris DG, McGee P, Fairclough P, et al. (2002) The tissue distribution of the mRNA of ghrelin and subtypes of its receptor, GHS-R, in humans. J Clin Endocrinol Metab. 87: 2988.

[140] Volante M, Allia E, Fulcheri E, Cassoni P, Ghigo E, Muccioli G, et al. (2003) Ghrelin in fetal thyroid and follicular tumors and cell lines: expression and effects on tumor growth. Am J Pathol. 162: 645-54.

[141] Park YJ, Lee YJ, Kim SH, Joung DS, Kim BJ, So I, et al. (2008) Ghrelin enhances the proliferating effect of thyroid stimulating hormone in FRTL-5 thyroid cells. Mol Cell Endocrinol. 285: 19-25.

[142] Riesco-Eizaguirre G, Santisteban P (2006) A perspective view of sodium iodide symporter research and its clinical implications. Eur J Endocrinol. 155: 495-512.

[143] Ueberberg B, Unger N, Saeger W, Mann K, Petersenn S (2009) Expression of ghrelin and its receptor in human tissues. Horm Metab Res. 41: 814-21.

[144] Kluge M, Riedl S, Uhr M, Schmidt D, Zhang X, Yassouridis A, et al. (2010) Ghrelin affects the hypothalamus-pituitary-thyroid axis in humans by increasing free thyroxine and decreasing TSH in plasma. Eur J Endocrinol. 162: 1059-65.

[145] Sosic-Jurjevic B, Stevanovic D, Milosevic V, Sekulic M, Starcevic V (2009) Central ghrelin affects pituitary-thyroid axis: histomorphological and hormonal study in rats. Neuroendocrinology. 89: 327-36.

[146] Spiess J, Villarreal J, Vale W (1981) Isolation and sequence analysis of a somatostatinlike polypeptide from ovine hypothalamus. Biochemistry. 20: 1982-8.

[147] Douglass J, McKinzie AA, Couceyro P (1995) PCR differential display identifies a rat brain mRNA that is transcriptionally regulated by cocaine and amphetamine. J Neurosci. 15: 2471-81.

[148] Kuhar MJ, Adams LD, Hunter RG, Vechia SD, Smith Y (2000) CART peptides. Reg Pept. 89: 1-6.

[149] Broberger C (1999) Hypothalamic cocaine- and amphetamine-regulated transcript (CART) neurons: histochemical relationship to thyrotropin-releasing hormone, melanin-concentrating hormone, orexin/hypocretin and neuropeptide Y. Brain Res. 848: 101-13.

[150] Couceyro P, Paquet M, Koylu E, Kuhar MJ, Smith Y (1998) Cocaine- and amphetamine-regulated transcript (CART) peptide immunoreactivity in myenteric plexus neurons of the rat ileum and co-localization with choline acetyltransferase. Synapse. 30: 1-8.

[151] Koylu EO, Couceyro PR, Lambert PD, Kuhar MJ (1998) Cocaine- and amphetamineregulated transcript peptide immunohistochemical localization in the rat brain. J Comp Neurol. 391: 115-32.

[152] Smith Y, Kieval J, Couceyro PR, Kuhar MJ (1999) CART peptide-immunoreactive neurones in the nucleus accumbens in monkeys: ultrastructural analysis, colocalization 
studies, and synaptic interactions with dopaminergic afferents. J Comp Neurol. 407: 491-511.

[153] Koylu EO, Couceyro PR, Lambert PD, Ling NC, DeSouza EB, Kuhar MJ (1997) Immunohistochemical localization of novel CART peptides in rat hypothalamus, pituitary and adrenal gland. J Neuroendocrinol. 9: 823-33.

[154] Kobayashi Y, Jimenez-Krassel F, Ireland JJ, Smith GW (2006) Evidence of a local negative role for cocaine and amphetamine regulated transcript (CART), inhibins and low molecular weight insulin like growth factor binding proteins in regulation of granulosa cell estradiol production during follicular waves in cattle. Reprod Biol Endocrinol. 4: 22.

[155] Wierup N, Gunnarsdottir A, Ekblad E, Sundler F (2007) Characterisation of CARTcontaining neurons and cells in the porcine pancreas, gastro-intestinal tract, adrenal and thyroid glands. BMC Neurosci. 8: 51.

[156] Hunter RG, Philpot K, Vicentic A, Dominguez G, Hubert GW, Kuhar MJ (2004) CART in feeding and obesity. Trends in endocrinology and metabolism: TEM. 15: 454-9.

[157] Leshan RL, Opland DM, Louis GW, Leinninger GM, Patterson CM, Rhodes CJ, et al. (2010) Ventral tegmental area leptin receptor neurons specifically project to and regulate cocaine- and amphetamine-regulated transcript neurons of the extended central amygdale. J Neurosci. 30: 5713-23.

[158] Koylu EO, Balkan B, Kuhar MJ, Pogun S (2006) Cocaine and amphetamine regulated transcript (CART) and the stress response. Peptides. 27: 1956-69.

[159] Vrang N, Tang-Christensen M, Larsen PJ, Kristensen P (1999) Recombinant CART peptide induces c-Fos expression in central areas involved in control of feeding behaviour. Brain research. 818: 499-509.

[160] Lakatos A, Prinster S, Vicentic A, Hall RA, Kuhar MJ (2005) Cocaine- and amphetamine-regulated transcript (CART) peptide activates the extracellular signalregulated kinase (ERK) pathway in AtT20 cells via putative G-protein coupled receptors. Neuroscience letters. 384: 198-202.

[161] Fekete C, Lechan RM (2006) Neuroendocrine implications for the association between cocaine- and amphetamine regulated transcript (CART) and hypophysiotropic thyrotropin-releasing hormone (TRH). Peptides. 27: 2012-8.

[162] Lopez M, Seoane L, Tovar S, Senaris RM, Dieguez C (2002) Thyroid status regulates CART but not AgRP mRNA levels in the rat hypothalamus. Neuroreport. 13: 1775-9.

[163] Fekete C, Mihaly E, Luo LG, Kelly J, Clausen JT, Mao Q, et al. (2000) Association of cocaine- and amphetamine-regulated transcript-immunoreactive elements with thyrotropin-releasing hormone-synthesizing neurons in the hypothalamic paraventricular nucleus and its role in the regulation of the hypothalamic-pituitarythyroid axis during fasting J Neurosci. 20: 9224-34.

[164] Rapport MM, Green AA, Page IH (1948) Serum vasoconstrictor, serotonin; isolation and characterization. J Biol Chem. 176: 1243-51.

[165] Berger M, Gray JA, Roth BL (2009) The expanded biology of serotonin. Annu Rev Med. 60: 355-66.

[166] Giarman NJ, Freedman DX (1960) Serotonin content of the pineal glands of man and monkey. Nature. 186: 480-1. 
[167] Ganguly S, Coon SL, Klein DC (2002) Control of melatonin synthesis in the mammalian pineal gland: the critical role of serotonin acetylation. Cell Tissue Res. 309: 127-37.

[168] Cooper R, Lerer B (2010) [The use of thyroid hormones in the treatment of depression]. Harefuah. 149: 529-34, 50, 49.

[169] Catini C, Legnaioli M (1992) Role of mast cells in health: daily rhythmic variations in their number, exocytotic activity, histamine and serotonin content in the rat thyroid gland. Eur J Histochem. 36: 501-16.

[170] Melander A, Sundler F (1972) Significance of thyroid mast cells in thyroid hormone secretion. Endocrinology. 90: 802-7.

[171] Melander A, Westgren U, Sundler F, Ericson LE (1975) Influence of histamine- and 5hydroxytryptamine-containing thyroid mast cells on thyroid blood flow and permeability in the rat. Endocrinology. 97: 1130-7.

[172] Tamir H, Hsiung SC, Liu KP, Blakely RD, Russo AF, Clark MS, et al. (1996) Expression and development of a functional plasmalemmal 5-hydroxytryptamine transporter by thyroid follicular cells. Endocrinology. 137: 4475-86.

[173] Falck B, Owman C (1968) 5-hydroxytryptamine and related amines in endocrine cell systems. Adv Pharmacol. 6: 211-31.

[174] Machado CR (1976) Monoamines in the C cells of the thyroid gland of callithricid primates. Histochemistry. 48: 187-90.

[175] Nunez EA, Gershon MD (1972) Synthesis and storage of serotonin by parafollicular (C) cells of the thyroid gland of active, prehibernating and hibernating bats. Endocrinology. 90: 1008-24.

[176] Zabel M (1984) Ultrastructural localization of calcitonin, somatostatin and serotonin in parafollicular cells of rat thyroid. Histochem J. 16: 1265-72.

[177] Bernd P, Gershon MD, Nunez EA, Tamir H (1981) Separation of dissociated thyroid follicular and parafollicular cells: association of serotonin binding protein with parafollicular cells. J Cell Biol. 88: 499-508.

[178] Tamir H, Liu KP, Hsiung SC, Adlersberg M, Nunez EA, Gershon MD (1990) Multiple signal transduction mechanisms leading to the secretion of 5-hydroxytryptamine by MTC cells, a neurectodermally derived cell line. J Neurosci. 10: 3743-53.

[179] Tamir H, Liu KP, Payette RF, Hsiung SC, Adlersberg M, Nunez EA, et al. (1989) Human medullary thyroid carcinoma: characterization of the serotonergic and neuronal properties of a neurectodermally derived cell line. J Neurosci. 9: 1199-212.

[180] Solcia E, Sampietro R (1968) New methods for staining secretory granules and 5hydroxytryptamine in the thyroid C-cells. In: Taylor S, Editor. Calcitonin: Proceedings of the symposium on thyrocalcitonin and the C cells. New York: Springer-Verlag. p. 127-32.

[181] Liu KP, Russo AF, Hsiung SC, Adlersberg M, Franke TF, Gershon MD, et al. (2003) Calcium receptor-induced serotonin secretion by parafollicular cells: role of phosphatidylinositol 3-kinase-dependent signal transduction pathways. J Neurosci. 23: 2049-57.

[182] Reiter RJ (1993) The melatonin rhythm: both a clock and a calendar. Experientia. 49: 654-64. 
[183] Lerner AB, Case JD, Takahashi Y (1958) Isolation of melatonin, pineal factor that lightens melanocytes. J Am Chem Soc. 80: 2057-8.

[184] Hardeland R, Fuhrberg B, Uria H, Behrmann G, Meyer TJ, Burkhardt S, et al. (1996) Chronobiology of indoleamines in the dinoflagellate Gonyaulax polyedra: metabolism and effects related to circadian rhythmicity and photoperiodism. Braz J Med Biol Res. 29: 119-23.

[185] Hardeland R, Poeggeler B (2003) Non-vertebrate melatonin. J Pineal Res. 34: 233-41.

[186] Voisin P, Namboodiri MA, Klein DC (1984) Arylamine N-acetyltransferase and arylalkylamine $\mathrm{N}$-acetyltransferase in the mammalian pineal gland. J Biol Chem. 259: 10913-8.

[187] Axelrod J, Weissbach H (1960) Enzymatic O-methylation of N-acetylserotonin to melatonin. Science. 131: 1312.

[188] Redman J, Armstrong S, Ng KT (1983) Free-running activity rhythms in the rat: entrainment by melatonin. Science. 219: 1089-91.

[189] Lewy AJ, Emens JS, Sack RL, Hasler BP, Bernert RA (2002) Low, but not high, doses of melatonin entrained a free-running blind person with a long circadian period. Chronobiol Int. 19: 649-58.

[190] Hack LM, Lockley SW, Arendt J, Skene DJ (2003) The effects of low-dose 0.5-mg melatonin on the free-running circadian rhythms of blind subjects. J Biol Rhythms. 18: 420-9.

[191] Sharkey KM, Fogg LF, Eastman CL (2002) Effects of melatonin administration on daytime sleep after simulated night shift work. J Sleep Res 10: 181-92.

[192] Reiter RJ, Tan DX, Maldonado MD (2005) Melatonin as an antioxidant: physiology versus pharmacology. J Pineal Res. 39: 215-6.

[193] Mogulkoc R, Baltaci AK, Oztekin E, Aydin L, Sivrikaya A (2006) Melatonin prevents oxidant damage in various tissues of rats with hyperthyroidism. Life Sci. 79: 311-5.

[194] Lewinski A, Karbownik M (2002) Review. Melatonin and the thyroid gland. Neuro Endocrinol Lett. 23 Suppl 1: 73-8.

[195] Witt-Enderby PA, Bennett J, Jarzynka MJ, Firestine S, Melan MA (2003) Melatonin receptors and their regulation: biochemical and structural mechanisms. Life Sci. 72: 2183-98.

[196] Pang SF, Dubocovich ML, Brown GM (1993) Melatonin receptors in peripheral tissues: a new area of melatonin research. Biol Signals. 2: 177-80.

[197] Ishii H, Tanaka N, Kobayashi M, Kato M, Sakuma Y (2009) Gene structures, biochemical characterization and distribution of rat melatonin receptors. J Physiol Sci. 59: 37-47.

[198] Rafii-El-Idrissi M CJ, Harmouch A, García-Mauriño S, Guerrero JM. (1998) Specific binding of melatonin by purified cell nuclei from spleen and thymus of the rat. J Neuroimmunol. 86: 190-7.

[199] Smirnov AN (2001) Nuclear melatonin receptors. Biochemistry (Mosc). 66: 19-26.

[200] Iuvone PM, Brown AD, Haque R, Weller J, Zawilska JB, Chaurasia SS, et al. (2002) Retinal melatonin production: role of proteasomal proteolysis in circadian and photic control of arylalkylamine N-acetyltransferase. Invest Ophthalmol Vis Sci. 43: 564-72. 
[201] Djeridane Y, Vivien-Roels B, Simonneaux V, Miguez JM, Pevet P (1998) Evidence for melatonin synthesis in rodent Harderian gland: a dynamic in vitro study. J Pineal Res. 25: 54-64.

[202] Konturek SJ, Konturek PC, Brzozowska I, Pawlik M, Sliwowski Z, CzesnikiewiczGuzik M, et al. (2007) Localization and biological activities of melatonin in intact and diseased gastrointestinal tract (GIT). J Physiol Pharmacol. 58: 381-405.

[203] Itoh MT, Ishizuka B, Kudo Y, Fusama S, Amemiya A, Sumi Y (1997) Detection of melatonin and serotonin $\mathrm{N}$-acetyltransferase and hydroxyindole-O-methyltransferase activities in rat ovary. Mol Cell Endocrinol. 136: 7-13.

[204] Itoh MT, Ishizuka B, Kuribayashi Y, Amemiya A, Sumi Y (1999) Melatonin, its precursors, and synthesizing enzyme activities in the human ovary. Mol Hum Reprod. 5: $402-8$.

[205] Carrillo-Vico A CJ, Abreu P, Lardone PJ, García-Mauriño S, Reiter RJ, Guerrero JM. (2004) Evidence of melatonin synthesis by human lymphocytes and its physiological significance: possible role as intracrine, autocrine, and/or paracrine substance. FASEB J. 18: 537-9.

[206] Naranjo MC, Guerrero JM, Rubio A, Lardone PJ, Carrillo-Vico A, Carrascosa-Salmoral MP, et al. (2007) Melatonin biosynthesis in the thymus of humans and rats. Cell Mol Life Sci. 64: 781-90.

[207] Fischer T.W. SA, Zmijewski M.A., Reiter R.J. and Paus R (2008) Melatonin as a major skin protectant: from free radical scavenging to DNA damage repair. Exp Dermatol. 9: 713-30.

[208] Tijmes M, Pedraza R, Valladares L (1996) Melatonin in the rat testis: evidence for local synthesis. Steroids. 61: 65-8.

[209] Garcia-Marin R, De Miguel M, Fernandez-Santos JM, A. C-V, Utrilla JC, Morillo-Bernal J, et al. (2012) Melatonin-Synthesizing Enzimes and Melatonin Receptors in rat Thyroid Cells. Histol Histopathol. Paper in press.

[210] Lewinski A, Sewerynek E (1986) Melatonin inhibits the basal and TSH-stimulated mitotic activity of thyroid follicular cells in vivo and in organ culture. J Pineal Res. 3: 291-9.

[211] Wright ML, Pikula A, Babski AM, Labieniec KE, Molan RB (1996) Effect of Melatonin on the Response of the Thyroid to Thyrotropin Stimulation in Vitro. Gen Comp Endocrinol. 108: 298-305.

[212] Makay B, Makay O, Yenisey C, Icoz G, Ozgen G, Unsal E, et al. (2009) The interaction of oxidative stress response with cytokines in the thyrotoxic rat: is there a link? Mediators Inflamm. 2009: 391682.

[213] Karbownik M, Lewinski A (2003) Melatonin reduces Fenton reaction-induced lipid peroxidation in porcine thyroid tissue. J Cell Biochem 90: 806-11.

[214] Rao MV, Chhunchha B (2010) Protective role of melatonin against the mercury induced oxidative stress in the rat thyroid. Food Chem Toxicol. 48: 7-10.

[215] Tan DX, Manchester LC, Reiter RJ, Plummer BF, Limson J, Weintraub ST, et al. (2000) Melatonin directly scavenges hydrogen peroxide: a potentially new metabolic pathway of melatonin biotransformation. Free Radic Biol Med. 29: 1177-85.

[216] Sainz RM, Mayo JC, Reiter RJ, Tan DX, Rodriguez C (2003) Apoptosis in primary lymphoid organs with aging. Microsc Res Tech. 62: 524-39. 
[217] Kameya T, Bessho T, Tsumuraya M, Yamaguchi K, Abe K, Shimosato Y, et al. (1983) Production of gastrin releasing peptide by medullary carcinoma of the thyroid. An immunohistochemical study. Virchows Arch A Pathol Anat Histopathol. 401: 99-107.

[218] Blaker M, de Weerth A, Tometten M, Schulz M, Hoppner W, Arlt D, et al. (2002) Expression of the cholecystokinin 2-receptor in normal human thyroid gland and medullary thyroid carcinoma. Eur J Endocrinol. 146: 89-96.

[219] Behr TM, Behe M, Angerstein C, Gratz S, Mach R, Hagemann L, et al. (1999) Cholecystokinin-B/gastrin receptor binding peptides: preclinical development and evaluation of their diagnostic and therapeutic potential. Clin Cancer Res. 5: 3124s-38s.

[220] Aloj L, Aurilio M, Rinaldi V, D'Ambrosio L, Tesauro D, Peitl PK, et al. (2011) Comparison of the binding and internalization properties of 12 DOTA-coupled and (1)(1)(1)In-labelled CCK2/gastrin receptor binding peptides: a collaborative project under COST Action BM0607. Eur J Nucl Med Mol Imaging. 38: 1417-25.

[221] Hoshino M, Yanaihara C, Hong YM, Kishida S, Katsumaru Y, Vandermeers A, et al. (1984) Primary structure of helodermin, a VIP-secretin-like peptide isolated from Gila monster venom. FEBS Lett. 178: 233-9.

[222] Parker DS, Raufman JP, O'Donohue TL, Bledsoe M, Yoshida H, Pisano JJ (1984) Amino acid sequences of helospectins, new members of the glucagon superfamily, found in Gila monster venom. J Biol Chem. 259: 11751-5. 